\title{
HUMAN RIGHTS REVISITED: THE PROTECTION OF HUMAN RIGHTS UNDER THE INTERNATIONAL COVENANT ON CIVIL AND POLITICAL RIGHTS
}

\author{
Matthew Lippman*
}

When you expand the civil rights struggle to the level of human rights, you can then take the case of the black man in this country before the nations in the United Nations. You can take it before a world court. But the only level you can do it on is the level of human rights. Civil rights keeps you under his restrictions, under his jurisdiction. Civil rights keeps you in his pocket . . . expand the civil rights struggle to the level of human rights, take it into the United Nations, where our African brothers can throw their weight on our side, where our Latin-American brothers can throw their weight on our side, and where 800 million Chinamen are sitting there waiting to throw their weight on our side.

Malcolm X

December 10, 1978 marked the thirtieth anniversary of the adoption of the Universal Declaration of Human Rights by the United Nations. ${ }^{2}$ In anticipation of this anniversary the Economic and Social Council and the General Assembly joined in recommending a general review of existing United Nations approaches to the promotion and observance of human rights. ${ }^{3}$

This article reviews the development of the Universal Declaration of Human Rights to determine whether the Declaration's promise of universal respect for and observance of human rights and fundamental freedoms has been fulfilled by the adoption of the

- Assistant Professor of Political Science, University of Denver. Northwestern University; Ph.D., 1975, American University; J.D., 1977.

1. Malcolm X, Malcolm X SPEAKs 23 (1966), as cited in Bilder, Re-Thinking International Human Rights: Some Basic Questions, 1969 WIS. L. REv. 171,183 n.19 (1969).

2. U.N. Doc. A/811 (December 10, 1965). The United Nations Declaration adopted the Universal Declaration of Human Rights by a vote of 48 in favor and 0 against. Eight States abstained - Byelorussian S.S.R., Czechoslovakia, Poland, Saudi Arabia, Ukraine S.S.R., U.S.S.R., Union of South Africa and Yugoslavia.

3. United Nations Office of Public Information, The United Nations and Human Rights. U.N. Doc. OPI/621, at 166 (1978). 
International Convention on Civil and Political Rights. ${ }^{4}$ The Civil and Political Covenant will also be examined, for, as one commentator remarked, the United Nations human rights instruments have "received much less systematic scholarly attention than have the comparable endeavours of various regional and specialized organizations."

\section{Historical Perspective}

\section{A. The Status of the Individual in International Law}

The Treaty of Westphalia in 1948 ushered in an international order based on the sovereignty and sovereign equality of nationstates. $^{6}$ Under this system the individual was not recognized as possessing any rights, while the nation-state retained complete discretion as to the way in which it treated both its nationals and stateless persons. This Westphalian view of the individual as having no rights or standing under international law has, up until recently, dominated jurisprudential thinking. ${ }^{7}$

4. U.N. Doc. A/PV. 1496, Provisional. The Covenant was unanimously adopted on December 16, 1966, 106 in favor and 0 against.

5. Buergenthal, International and Regional Human Rights Law and Institutions: Some Examples of Their Interaction, 12 TEX. INT'L L.J. 321, 321 (1977). Individuals interested in exploring the literature in the human rights field should consult: FUNDAMENTAL RIGHTS (J. Bridge, D. Lasok, D. Perrott and R. Plender eds. 1973); J. Carey, U.N. Protection of Civil and Political Rights (1970). Comparative Human Rights (R. Claude ed. 1976); M. Cranston, What are Human Rights (1962); A. Del. Russo, International Protection of Human Rights (1971); P. Drost, Human Rights As Legal Rights (1965); I. Duchacek, Rights \& Liberties In The World Today: Constitutional Promise \& Reality (1973); International Protection of Human Rights (A. Eide and A. Schou eds. 1968) (Nobel Symposium 7); M. Ganj, International Protection of Human Rights (1962); E. HaAs, Human Rights and International action (1970); The Human Right To Individual Freedom (L. Kutner ed. 1970); H. Lauterpacht, INTERnational Law and Human Rights (1950); The International Protection of Human Rights (E. Luard ed. 1967); J. Maritain, The Rights of Man and Natural Law (D. Anson trans. 1943); Human Rights (A. Melden ed. 1970); M. Moskowitz, InTERNATIONAL Concern With Human Rights (1974); Human Rights in National and International Law (A. Robertson ed. 1968); A. Robertson, Human Rights in the World (1972); E. Schwelb, Human Rights and the International Community (1964); L.B. Sohn and T. Buergenthal, International Protection of Human Rights (1973); United Nations, United Nations Action in the Field of Human Rights U.N. Doc. ST/HR/2 (1974); United Nations, The Realization of Economic Social and Cultural Rights: Problems, Policies, Progress U.N. Doc. E/CN.4/1131/Rev.l (1974); AN InTRoduction to THE Study of Human Rights (F. Vallat ed. 1972); V. Van Dyke, Human Rights, The United States, ANd World Community (1970).

6. See Lane, Demanding Human Rights: A Change in the World Legal Order, 6 HofSTRA L. REV. 269 (1978).

7. I.L. Oppenheim, International Law: A Treatise $\$ 292$, at 641 (8th ed. H. Lauterpacht ed. 1955). For a contrary point of view see generally H. LAUTERPACHT, supra note 
The orthodox positivist doctrine has been explicit in the affirmation that only states are subjects of international law. In those cases in which individuals seem to derive benefits under international law, the predominant view has been that such benefits are enjoyed not by virtue of a right which international law gives to the individual, but by reason of a right appertaining to the State of which the individual is a national. . . . Similarly, if individuals have no rights under international law, it seems to follow that they can have no locus standi before international tribunals and other international agencies. ${ }^{8}$

The traditional status of the individual in international law is recognized by Oppenheim.

Since the Law of Nations is based on the common consent of individual states, and not of individual human beings, States solely and exclusively . . . are the subjects of International Law. This means that the Law of Nations is a law for international conduct of States, and not of their citizens. . . . An individual human being . . . is never directly a subject of International Law. ${ }^{9}$

But what is the real position of individuals in International Law, if they are not subjects thereof? The answer can only be that they are objects of the Law of Nations. ${ }^{10}$

Since the individual can never be "the subject" of international law, the individual can only obtain rights through an international treaty indirectly, through the act of "transformation" by the individual's nation-state.

[T] he traditional theory has denied the possibility of any direct relation between international and municipal law. If individuals can never be subjects of international rights and duties then according to that view, the rules of international law can have no immediate effect, without a previous act of transformation, upon the municipal law of the State. ${ }^{11}$

Traditionally, alien residents who were entitled to be treated in accordance with the "minimum standards of civilization," were the only individuals recognized as having rights under international

5, G. Ezejiofor, Protection of Human Rights Under the Law (1964). There is general agreement that a state may assume legal obligations towards individuals by virtue of an international agreement. See Case Concerning the Jurisdiction of the Courts of Danziq, [1928-30] P.C.I.J. Ser. B., No. 15.

8. H. LAUTERPACHT, supra note 5, at 6-8.

9. I.L. Oppenheim, International Law: A Treatise, para. 13, at 20-21 (A.D. McNair ed. 1928).

10. Id para. 290 , at 521 .

11. H. LAUTERPaCHT, supra note 5 , at 8. 
law. ${ }^{12}$ These rights were qualified by the fact that any right of action arising from a violation of a state's duty towards the alien resident resided exclusively in the alien's state of nationality, with any compensation received for the injury belonging to that state. The Permanent Court of International Justice observed that "[b]y taking up the case of one of its subjects and by resorting to diplomatic action or international 'judicial' proceedings on his behalf, a State is in reality asserting its own rights-its right to ensure, in the person of its subjects, respect for the rules of International Law."13

The individual's lack of status in classical international jurisprudence has been matched by the failure of international diplomacy and customary international law to address, until recently, the matter of individual human rights.

\section{B. International Efforts Prior to World War II}

Prior to the nineteenth century nation-states demonstrated little concern for the international human rights of individuals. ${ }^{14}$ Those limited efforts in the field of human rights focused on the self-determination of peoples, the prohibition of slavery, religious freedom and the regulation of the prohibition of the law against war. ${ }^{15}$

Nineteenth century efforts at encouraging the self-determination of peoples were motivated by a desire to serve nation-state selfinterest. For instance, British efforts to foster independence for the Spanish colonies of Latin America furthered British commercial and political interests. ${ }^{16}$ The British activity of establishing independent states from the control of the Ottoman and Austrian

12. Lillich, Forcible Self-Help by States to Protect Human Rights, 53 Iowa L. Rev. 325, 327 (1967).

13. Mavrommatis Jerusalem Concessions Case, [1927] P.C.I.J., ser. A., Vol. 2, No. 10. See also Nottebohm Case (second phase) [1955] I.C.J. 4, 24. A thorough discussion is contained in Brownlie, The Place of the Individual in International Law, 50 VA. L. REV. 441, 461 (1964); Bin Cheng, The Contribution of International Courts and Tribunals to the Protection of Human Rights Under International Customary Law, in A. Eide and A. Schou eds., supra note 5 , at 167. Another option available to states, in certain situations, is forcible self-help, see generally Lillich, supra note 12 , at 325.

14. H. LaUterpacht, supra note 5, at 120.

15. See generally Burns, The Rights of Man Since the Reformation: An Historical Study, in F. Vallat ed., supra note 5, at 16; Castberg, Natural Law and Human Rights: An IdeaHistorical Survey, in A. Eide and A. Schou eds., supra note 5; Luard, The Origins of International Concern Over Muman Rights, in E. Luard ed., supra note 5, at 7; H. LAUTERPACHT, supra note 5, at 73-141; Said, Pursuing Human Dignity in Human Rights and World Order (A. Said ed. 1978).

16. Luard, in E. Luard ed., supra note 5, at 10. 
Empires, while furthering human rights, was also designed to frustrate Russian expansionism. ${ }^{17}$

Not all international human rights concerns were centered in domestic policy. Slavery was an issue which evoked international concern to such a degree that it was abolished by the seventeen signatory nations to the 1890 Brussels Agreement. ${ }^{18}$ International indignation and protest was also evoked by the war atrocities committed by Turkish troops in Bulgaria in 1876 and Armenia in 1894. Anger was also aroused by Russian pogroms against the Jews in 1891, and by King Leopold's repressive administration of the Congo in 1905. ${ }^{19}$ However, it was the barbarities of the Crimean War which finally awakened the Western World to the necessity of protecting the rights of both combatants and non-combatants. ${ }^{20}$ The Declaration of Paris of 1856 set forth principles governing neutral shipping and prohibiting privateering. ${ }^{21}$ In 1856, the Declaration of St. Petersburg outlawed the use of certain types of explosives and inflammable bullets, and the Geneva Convention of 1864 laid down conditions governing the treatment of wounded in the field. ${ }^{22}$ This movement culminated in the Hague Conferences of 1899 and 1907, which established detailed rules for land and naval warfare as well as for the treatment of prisoners of war. ${ }^{23}$

Individual States also began to incorporate clauses in their treaties guaranteeing freedom of religious practice as a means of insuring international peace. For example, general religious rights were assured for the people of Serbia, Montenegro and Rumania under the Treaty of Berlin in $1878 .^{24}$

Overall, these early international efforts at protecting human rights

remained for the most part spasmodic and unorganized. [They] had few recognized channels of expression. . . . And only on matters arousing especially intense feelings, such as slavery, the treatment of prisoners and wounded in war, or over specific atrocities attracting widespread publicity, such as those in

17. Id.

18. See McDougal, Lasswell and Chen, The Protection of Respect and Human Rights: Freedom of Choice and World Public Order, 24 AM. UNIV. L. REv. 919, 958-60 (1975).

19. Luard, in E. Luard ed., supra note 5, at 12-13.

20. Id.

21. Id.

22. Id.

23. See Gutteridge, War and Human Rights, in F. Vallat ed., supra note 5, at 99.

24. Id. at 13. Luard, in E. Luard ed., supra note 5, at 13. Prior to this time efforts had been made by members of one religion exclusively on behalf of their co-religionists. 
Bulgaria or the Congo, was any effective action normally taken. 25

The formation of the League of Nations at the end of World War I was perhaps the first attempt at providing individuals with both a right and a remedy under international law. ${ }^{26}$ Although the protection of human rights received little overall discussion at the Versailles Conference, ${ }^{27}$ the question of the rights of minorities within a state dominated by another nationality received a great deal of attention. ${ }^{28}$

On the one hand, with the disappearance of multi-national, nonracial states, such as the old Austro-Hungarian and Turkish Empires, almost every European nation came to be dominated by a single nationality which, without special measures of protection, might abuse its position at the expense of the minorities. On the other [hand], the ideal of self-determination itself presupposed a special concern to protect all national groups even if, for reasons of their geographical distribution, they were not able to enjoy that right in a direct form. ${ }^{29}$

Pragmatic motivations were also behind this concern for minorities. President Wilson observed that the "Great Powers" did not want to leave "elements of disturbance unremoved which ... would disturb the peace of the world." 30

With this concern for minority groups, "all new or substantially enlarged states then coming within the purview of the [New States] Committee's work," were required to assume obligations for the protection of their minorities "as a condition to the recognition by the Powers of their independence or new frontiers, or of their admission to the League." ${ }^{31}$ The treaties stipulated that their provisions established obligations of international concern placing the rights of "persons belonging to racial, religious or linguistic minori-

25. Id. at 14 .

26. Id.

27. Id.

28. See generally Macartney, League of Nations Protection of Minority Rights, in E. Luard ed., supra note 5, at 22; P. Anker, The Mandates System: Origin-Principles-Application (L.N. Publ. 1945.VI.A.1); H. Hall, Mandates, Dependencies and Trusteeship (1948); O. Wright, Mandates Under the League of Nations (1930).

29. Luard, in E. Luard ed., supra note 5, at 14.

30. Id. at 24.

31. Macartney, in E. Luard ed., supra note 5, at 23, lists the instruments under League Control as: Treaties: Poland, Czechoslovakia, Austria, Romania, Yugoslavia, Greece, Bulgaria, Hungary, Turkey. Declarations: Albania, Lithuania, Latvia, Estonia, Iraq. Local Conventions: Poland and Danzig, Finland, Germany and Poland, Memel. Conventions on exchange of populations: Greece and Bulgaria, Greece and Turkey. 
ties" "under the guarantee of the League of Nations." 32 The minority treaties ${ }^{33}$ "guaranteed such rights as freedom from discrimination in civil and political affairs, and the free exercise of speech and religion." Any member of the Council of the League had standing to bring to the attention of the Council any state infringement of treaty obligations. The Council was authorized to take such action as it felt proper, and, as a last resort, disputes could be submitted to the International Court of Justice for settlement. ${ }^{34}$ The cumulative effect of these provisions was to change the entire relationship between those persons in the designated minorities and their country of residency or citizenship. In theory, the countries obligated under the minority treaties were no longer free to act with unlimited discretion toward protected minorities. ${ }^{35}$

The states subject to the minority treaties thus perceived themselves as having been singled out for persecution, while, at the same time, the administrative ineffectiveness of the League lead to the alienation and frustration of minority groups in the treaty states. The League minority protection system was also criticized for having failed to provide protections for those minority groups who were later to suffer persecution, such as the Jews in Germany and national minorities in the Soviet Union. ${ }^{36}$ This failure of the League minority protection system, coupled with the massive human rights violations accompanying World War II, served to

32. Id. at 25 .

33. Id.

34. For details of the minority treaties, see id. at $27,28$.

35. Ferguson, The United Nations Human Rights Covenants; Problems of Ratification and Implementation, Proceedings of the american Society of International Law, Sixty-Second ANnual Meeting (April 25-27, 1968) 83, 85. For the international human rights established in the treaties, see $M$. GANJI, supra note 5, at 46.

36. The League of Nations did leave a significant legacy of human rights and humanitarian activities which has served as an inspiration to the human rights program of the United Nations. A Committee on slavery undertook a study of slavery in the world and was responsible for an anti-slavery convention in 1922. An Advisory Committee on the Traffic in Women and Children was also established. A refugees' organization which survived the life of the league secured resettlement of over two million refugees from Russia, Turkey and Eastern Europe. Another central achievement was the establishment of an International Labor Organization. A Committee on Traffic in Opium and Other Dangerous Drugs also was formed. Other activities involved a Committee on International Co-operation which promoted intellectual freedom and the position of intellectuals. A health office, predecessor to the World Health Organization, was active in the area of public health. An organization known as the International Relief Union worked in disaster relief. Additionally, a mandate system was established in former German and Turkish colonies. The mandate system was based on the principle that such people "form a sacred trust of civilization," Luard, in E. Luard ed., supra note 5, at 16-21. Luard suggests that these developments assisted in the development of viewing individuals as possessing rights under International Law. Id. at 21 . 
motivate the Allied Powers to consider a comprehensive international human rights program.

\section{EARly U.N. Human Rights Activity}

\section{A. The U.N. Charter}

World War II heightened the awareness of the Allied Powers to human rights. The Allied war aims proclaimed by President Roosevelt in his "four freedoms" speech to the United States Congress on January 6, 1941 were; freedom of speech, freedom of worship, freedom from want and freedom from fear throughout the world. ${ }^{37}$ Roosevelt referred to these "four freedoms" as "necessary conditions of peace," and emphasized that these were not ideals of a "distant millennium." 38 Subsequently, on August 14, 1941, the Atlantic Charter was signed, with the hope that following the destruction of Nazi tyranny there would be established "a peace which will afford to all nations the means of dwelling in safety within their own boundaries, and which will afford assurance that all the men in all the land may live out their lives in freedom from want and fear." 39 This concern for international human rights was reiterated in the Declaration of United Nations of January 1, $1942 .{ }^{40}$ The Declaration stated that "complete victory over their enemies [was] essential to defend life, liberty, independence and religious freedom, and to preserve human rights and justice in their own lands as well as in other lands." 41

In 1944, representatives of the Soviet Union, United Kingdom, United States and China met at Dumbarton Oaks in Washington D.C. and agreed to form the United Nations; an international organization designed to achieve peace and cooperation among na-

37. 87 Cong. ReC., H46-47, 77th Cong., 1st Sess. (Daily ed. Jan. 6. 1941).

38. Id.

39. Quoted in Humphrey, The U.N. Charter and the Universal Declaration of Human Rights, in E. Luard ed., supra note 5, at 39.

40. Id.

41. Id. at 40, EzEJIOFOR, supra note 7, at 54. Another example of human rights protection inspired by the Second World War are the Paris Peace Treaties of 1947 in which each of the defeated states undertook "to take all measures necessary to secure to all peoples under its jurisdiction," without distinction as to race, sex, language or religion, "[t]he enjoyment of human rights and fundamental freedoms," including freedom of expression, freedom of the press and publication, freedom of religious worship and freedom of political opinion and public meeting. See the following treaties, Italy article 15; Romania article 3(1); Bulgaria article 2, and 30 (1948); Martin, Human Rights in the Paris Peace Treaty, 24 Brit. YearbOOK INT'L L. 392-98 (1947); see also Interpretation of Peace Treaties, [1950] I.C.J. Rep. 65 and 27; and discussion in Humphrey, supra note 39, at 40. 
tions. One of the proposed purposes of the United Nations was "international cooperation in the solution of international economic, social and other humanitarian problems and the promotion of respect for human rights and fundamental freedoms." 42 These purposes served as an inspiration for the various provisions of the United Nations Charter pertaining to human rights. ${ }^{43}$ The Charter recognizes that the maintenance of international peace and security and the protection of human rights are interdependent, ${ }^{44}$ and it proclaims the promotion of human rights as one of the major aims of the United Nations. ${ }^{45}$ It provides a framework for the development of United Nations organs concerned with human rights, ${ }^{46}$ and it provides for the drafting of instruments in the field of human rights. ${ }^{47}$ It also imposes upon both the member states and the or-

42. See G. EzEJIOFOR, supra note 7, at 54-55. The original Dumbarton Oaks proposal on human rights sponsored by the Soviet Union, United States, United Kingdom and China read:

With a view to the creation of conditions of stability and well-being which are necessary for the peaceful and friendly relations among nations, the organization should facilitate solutions of international economic, social and other humanitarian problems and freedoms. Responsibility for the discharge of this function should be vested in the general assembly in the Economic and Social Council.

As a result of pressure from smaller nations and private N.G.O.'s this was amended at the San Francisco Conference to read:

With a view to the creation of stability and well-being which are necessary for the peaceful and friendly relations among nations based on respect for the principle of equal rights and self-determination of peoples, the organization should facilitate solutions of international economic, social, cultural and humanitarian problems and promote respect for human rights and fundamental freedoms for all without distinction as to race, language, religion and sex. Responsibility for the discharge of this function should be vested in the General Assembly in the Economic and Social Council.

43. Humphrey, in E. Luard ed., supra note 39, at 39; G. EzEJIOFOR, supra note 7, at 5455. Humphrey credits the incorporation of these protections in the Charter to the efforts of certain small countries and forty-two private organizations present as consultants to the United States delegation. Sohn comments on the motivation behind inclusion of the human rights clauses in the United Nations Charter:

The reasons for including these provisions in the Charter were many. Some countries, such as the United States and France, have long pioneered in the development of Bills of Rights for the protection of their own citizens, and their representatives felt that humanity as a whole should benefit from their experience. Others wanted to prevent the repetition of the totalitarian atrocities of the 1930's which shocked the conscience of mankind. Another group, dissatisfied with the workings of the minority treaties which were imposed on some states of Eastern Europe and the Middle East after the First World War, felt that the problem of protection of minorities can be solved only in the broader framework of a Bill of Rights applicable to all.

Sohn, as quoted in L.B. Sohn AND T. Buergenthal, supra note 5, at 504-06.
44. Id. at 41 .
45. Id.
46. Id. at 42 .
47. Id. 
ganization a responsibility to promote human rights. ${ }^{48}$

The first explicit reference in the United Nations Charter to human rights is in the second clause of the Preamble, ${ }^{49}$ ironically drafted by Field Marshal Smuts of South Africa. ${ }^{50}$ It states that the "peoples of the United Nations", not merely limited to the member states or organizations, "reaffirm faith in fundamental human rights, . . . in the dignity and worth of the human person" and in the "equal rights of men and women."

The second explicit reference to human rights is found in Article 1(3), which includes among the stated "Purposes and Principles" of the United Nations, the achievement of "international cooperation in solving international problems of an economic, social, cultural, or humanitarian character, and in promoting and encouraging respect for human rights and for fundamental freedoms for all without distinction as to race, sex, language, or religion. . . ."51

48. McDougal and Bebr, Human Rights In The United Nations, 58 AM. J. INT'L L. 603, 612 (1964).

49. G. EzEJIOFOR, supra note 7, at 56.

50. Smuts was a strong verbal advocate of human rights at the San Francisco Conference. G. EzejIOFOR, supra note 7, at 56 quotes Smuts' statement at the 6th Plenary Session, 1st May 1948:

I would suggest that the Charter should contain at its very outset, and in the preamble, a declaration of human rights and of common faith which had sustained the Allied Peoples in their bitter and prolonged struggles for the vindication of these rights and that faith . . . We have fought for justice and decency and for the fundamental freedoms and rights of man, which are basic to all human advancement and progress and peace.

Some would argue that General Smuts' close involvement in the human rights movement at the San Francisco Conference is evidence of the purely "symbolic" intent behind the human rights provisions. Conversation with Dr. Martin Chanock, Senior Lecturer, Legal Studies Department, La Trobe University. This argument, may have validity, but Smuts' advocacy of human rights cannot be utilized as evidence that all governments viewed the human rights movement as "symbolic." For instance, some smaller states were proponents of a strong U.N. human rights program. Chile, Cuba and Panama all put forward proposals which would have made the United Nations guarantee the protection of specified human rights. Panama urged incorporation of a bill of rights. These proposals were rejected as giving the new organization too much power in the sensitive area of human rights. In the end, drafting of additional protections was left to the Human Rights Commission, Humphrey, in E. Luard ed., supra note 5 , at $40,41$.

51. L.B. SOHN AND T. BUergenthal, supra note 5, at 510-11 contains comments by L.B. Sohn on the history of article 1(3). At the San Francisco Conference, Committee I/1 adopted the sponsoring powers' proposal for the promotion and encouragement of respect for human rights with only minor drafting changes. Costa Rica questioned whether "promote" might not only authorize the propagation of ideas and principles by the U.N., but also authorize the coercion of states to comply with human rights principles. Costa Rica objected to any authorization of the United Nations to use coercion and wanted it stated that the functions of the organization "are purely cultural." In contrast, other delegations suggested that "promote" be replaced by stronger phraseology such as "to assure" or "to protect." The Committee held that "assuring or protecting human rights was the concern of each state, 
Article 13(b) imposes the obligation on the General Assembly to "initiate studies" and "make recommendations" for the purpose of "promoting international cooperation in the economic, social, cultural, educational and health fields, and assisting in the realization of human rights and fundamental freedoms for all without distinction as to race, sex, language or religion." Much of the human rights and humanitarian work of the General Assembly and the Third Committee, which concerns itself with social, humanitarian and cultural affairs, is authorized under Article 13. Additional provisions respecting human rights include Articles $55(\mathrm{c}),{ }^{52} 56,{ }^{53}$

unless such rights and freedoms were so grievously outraged so as to threaten international peace or obstruct the application of the Charter." Despite the modest language of article 1(3), Humphrey, in E. Luard ed., supra note 5, at 41, points out that it is "of more than rhetorical importance." Article 1(3) has been used on a number of occasions as an international standard to which states should conform. In a report submitted to the General Assembly by the United Nations Commission on the racial situation in the Union of South Africa it was stated that certain measures adopted by that country were contrary to the purposes of article 1(3) of the Charter. See Repertory of Practice of United Nations Organization, Supp. No. 1, Vol. 1, Art. 1, para. 21. Another example of reference being made to article 1(3) was in 1955 when the General Assembly instructed its Committee on Information From NonSelf-Governing Territories to examine summaries and analyses of article 73(e) "in the spirit of article 1, paras. 3 and 4". According to Humphrey, "it is clear that the Assembly can and will undertake investigations, and make recommendations to member states, concerning the application of the purposes of the organization . . Humphrey, in E. Luard ed., supra note 5 , at $41-42$.

52. At the San Francisco Conference, "Committee II/3 incorporated into the text of article 55 of the Charter an Australian proposal that the Organization should promote not only respect for human rights, but also their 'observance.'" This was explained as an attempt to strengthen article 55. "Respect" was interpreted by Australia to connote passivity and the addition of "observance" was intended to imply active implementation and an obligation on state parties to implement the provisions of article 55. L.B. SoHN AND T. BUERGENTHAL, supra note 5, at 511.

53. Humphrey, in E. Luard ed., supra note 5, at $42-43$ comments that articles 55 and 56 "probably creates the only clear legal obligations in the Charter on members to promote respect for human rights. Humphrey supports this argument by pointing to the language of various United Nations resolutions. For instance, a 1952 General Assembly resolution on South Africa stated that "governmental policies of member states which are not directed towards these goals (e.g. equality before the law), but which are designed to perpetuate or increase discrimination, are inconsistent with the pledges of the members under article 56 of the Charter." J. CAREY, supra note 5, at 168 agrees with Humphrey and quotes U. Thant as commenting in reference to article 56 that "Perhaps the boldest innovation of the Charter was the unconditional and universal obligation in regard to human rights and fundamental freedoms," Statement at opening of forty-fifth session of ECOSOC Geneva, July 8, 1968. U.N. press release SG/SM/971 - ECOSOC/2474 (1968).

Note: Article 56 refers to action in "cooperation with the organization." The Dumbarton Oaks proposals contained no such provision while the San Francisco Conference contemplated a three-fold pledge to take "separate and joint action" and "to co-operate with the organization." Although Article 56 precludes any obligation to take any action independent of the United Nations, L.M. Goodrich and E.I. Hambro suggest that it obligates Member States, "to refrain from obstructionist acts and to co-operate in good faith in the achievement 
$62(2)^{54}$ and $68 .^{55}$

The final explicit reference to human rights in the Charter is Article 76(1), which establishes as one of the basic objectives of the United Nations trusteeship system, inter alia, the obligation of member states

c. to encourage respect for human rights and for fundamental freedoms for all without distinction as to race, sex, language or religion. ${ }^{56}$

Various other articles of the Charter, though not including explicit human rights provisions, may, in certain circumstances, pro-

of the purposes of Article 56." L.M. GoOdRICH AND E.I. HAMbro, The Charter of THE UNited Nations 320 (1946). The history of Article 56 is confused. Both the pledge in Article 56 and the full employment clause in Article 55(a) originated in an Australian proposal according to which members of the United Nations were to take action to secure "economic rights, for all who seek it." The United States objected that the language of Articles 55 and 56 might involve the United Nations in the domestic affairs of Member States and pursuant to the United States' objection it was agreed that the report of the Committee should state explicitly that "nothing contained in Chapter IX can be construed as giving authority to the Organization to intervene in the domestic affairs of member states." Sohn, in L.B. SoHn AND T. Buergenthal, supra note 5, at 512-13. The United States also objected to a proposal of Sub-committee II/3/A that members of the United Nations should "pledge themselves to take separate and joint action to cooperate with the Organization and with each other to achieve these purposes." Australia interpreted this to require Nations to pursue this objective both within the United Nations and within the domestic sphere. The Sub-committee revised the original draft to require Nations to "undertake to co-operate jointly and severally with the Organization for the achievement of these purposes." This modification in phraseology was justified by the United States on the familiar grounds that any requirement of "separate" action might justify intervention in the domestic affairs of member states.

Article 56 reaffirms the requirements of Article 55 and contains what appears to be the clearest commitment to human rights in the U.N. Charter. "All Members pledge themselves to take joint and separate action in co-operation with the Organization for the achievement of the purposes set forth in Article 55."

54. 62(1) empowers the Economic and Social Council to initiate studies and reports with respect to ". . . international economic, social, cultural, educational, health and related matters. . . Although human rights are not mentioned specifically, Article 62 has served as a basis for the Council undertaking, though the Commission on Human Rights and other bodies, many reports, studies and draft conventions.

55. Article 68 is the constitutional basis for the Commission on Human Rights which has performed the basic work in drafting the Universal Declaration of Human Rights and other human rights declarations. Reference to "promoting" respect for human rights was included after a plea by the United States that the Commission "was expected and hoped for by a great many people and there would be a profound disappointment if it were not adopted." Sohn, in L.B. Sohn AND T. BuErgenthal, supra note 5, at 511-12.

Article 68 inter alia provides that the Economic and Social Council "shall set up commissions . . . for the promotion of human rights."

56. J. CAREY, supra note 5, at 143-53 argues that the trusteeship system creates a "double standard" of protection for human rights by providing greater protection to inhabitants of trustee states than is provided to inhabitants of independent, member states. See also H. LAUTERPACHT, supra note 5, at 160-61. 
vide authorization for human rights activities by United Nations organs. For instance, Article 10 permits the General Assembly to "discuss any questions or any matters within the scope of the present Charter," and Article 11(2) permits the General Assembly to "discuss any questions relating to maintenance of international peace and security." The Security Council, under Chapter VII, Article 39 , shall "determine the existence of any threat to the peace, [or any] breach of the peace . . . and shall make recommendations, or decide what measures shall be taken." Article 66(2) authorizes the Economic and Social Council to "perform services at the request of members of the United Nations," and provides the constitutional basis for the advisory services program in human rights under which training fellowships are awarded, seminars are organized and expert assistance is provided to members. ${ }^{57}$

Despite the Charter's expression of concern, "two obvious weaknesses with respect to human rights are the lack of implementation machinery and a failure to define human rights." 58 However, as suggested by President Truman's statement, the expectation at the San Francisco Conference was that the definition and implementation of the human rights provisions would be quickly forthcoming.

Under this document [the Charter] we have good reason to expect an international bill of rights acceptable to all nations involved. That bill of rights will be as much a part of international life as our own Bill of Rights is part of our Constitution. The Charter is dedicated to the achievement and observance of human rights and fundamental freedoms. Unless we can attain those objectives for all men and women everywhere without regard to race, language or religion, we can not have permanent peace and security in the world. ${ }^{59}$

A bill of rights embodied in the Charter would have had great

57. For a description of such programs, see United Nations, Unired Nations Action in the Field of Human Rights 192 (1974); R. ClaRK, A United Nations High Commissioner FOR HUMAN RIGHTS 29-30 (1972).

58. G. EZEJIOFOR, supra note 7, at 59.

59. 1 U.N.C.I.O. Docs. 717 (1945). Sohn, in L.B. Sohn AND T. BUergenthal, supra note 5, at 507-10, details the efforts to include a bill of rights in the Charter. Early drafts of the United Nations Charter prepared by the United States Department of State in 1942 included a bill of rights containing "a common program of human rights" to which United Nations members would have to subscribe. Disagreement arose over inclusion of socio-economic rights and measures of implementation. An additional draft of August 14, 1943 included an instrument entitled a "Declaration of Human Rights." A provision of the Draft Charter specified that:

The Members of the United Nations agree to give legislative effect to the Declaration of Human Rights annexed to this Charter. Measures of enforcement shall be 


\section{moral force and authority. Humphrey remarks that, "It is a matter for regret therefore that the opportunity provided by the San Fran-}

applied by the administrative and judicial authorities of each Member without discrimination as to nationality, language, race, political opinion, or religious belief.

In April of 1944 the United States abandoned the idea of preparing a Declaration on Human Rights. The United States "Plan for a General International Organization" only contained a provision empowering the General Assembly to initiate studies and make recommendations for "the promotion of the observance of basic human rights in accordance with principles or undertakings agreed upon by the states members of the international organization." The provision was included in the United States "Tentative Proposals for a General International Organization" submitted to the Dumbarton Oaks Conference by the United States. At that Conference, the United Kingdom suggested that one of the purposes of the United Nations should be to "guard man's freedom by institutions for removing social wrongs" while China proposed that the United Nations should be based on the principle of equality of races as well as states. In the end, British and Soviet objections to inclusion of specific human rights obligations in the Charter resulted in the Dumbarton Oaks proposals containing only one general reference to United Nations promotion of human rights and fundamental freedoms. See G. EzEJIOFOR, supra note 7.

At the San Francisco Conference a large number of human rights amendments were submitted. The Sponsoring Governments attempted to compromise by agreeing to incorporate references to the promotion of human rights and nondiscrimination in the statement of purposes (later article 1), in the powers of the General Assembly (later article 1), in the powers of the Economic and Social Council (later article 62), in the statement of economic and social goals (later article 55), and in the provision relating to the setting up of commissions by the Economic and Social Council (later article 68). In explaining these additions to the Charter, Mr. Edward R. Settinius, Jr., United States Secretary of State noted that they "are essential if we are to build peace on the basis of justice and freedom for all" and that the people of the world "rightly demand the active defense and promotion of basic human rights and fundamental freedoms. It is a matter of elementary justice that the demand be answered affirmatively." He expressed the hope that the proposed Commission on Human Rights will "promptly undertake to prepare an international bill of rights which can be accepted by all the member nations as an integral part of their own systems of law, just as our Bill of Rights has been an integral part of our system of Law."

Other proposals for human rights protection in the Charter should be noted. Field Marshal Smuts of South Africa suggested that "declaration of human rights" be placed in the Preamble of the Charter. See G. Ezejlofor, supra note 7, at 56. A Columbian submission called for the Preamble to recognize that individual rights are a "necessary condition of peace"; a Panamanian proposal suggested inclusion of an "International Bill of Rights" in the Charter, Uruguay and then in a separate proposal, Mexico, Equador and Chile called for imposing obligations guaranteeing the "full and complete protection of rights"; Norway urged that a human rights clause, in addition to being included in the state of Purposes of the United Nations, be included in the Statement of Principles. Norway pointed out that this would strengthen human rights protections since expulsion is available as a sanction for violation of Principles but not for contravention of Organizational Purposes. A New Zealand proposal urged inclusion of the "Four Freedoms" in the Charter and a joint proposal sponsored by Brazil, the Dominican Republic and Mexico and a separate Indian proposal, both successfully urged insertion of a human rights and anti-discrimination clauses among the Purposes of the organization. The inclusion in the Charter of a bill of rights was not undertaken due to a "lack of time" at the San Francisco Conference. See Doc. 723 I/1/A/9, at 10 (1945), 6 U.N.C.I.O. Docs., at no. 5. An excellent discussion of these proposals is contained in Huston, Human Rights Enforcement Issues Of The United Nations Conference On International Organization, 53 IOWA L. Rev. 272 (1967). 


\section{cisco Conference, when the bill might have been adopted on a wave of enthusiasm, was lost." 60}

\section{Despite the Charter's two "obvious weaknesses," its recogni- tion of human rights is of great historical moment:}

The Charter of the United Nations presents a radical departure from previous approaches to the international protection of human rights. For some 3,000 years the concern of the international community was restricted to the treatment of foreigners, and various procedures were devised for dealing with claims of a citizen of one country against another country for wrongs suffered in the territory of the second country, or due to violations of international law by its officials, citizens or inhabitants. Only a hundred years ago, the international community expressed its interest in the fate of minorities in limited areas of Europe, and in the fate of people inhabiting certain parts of Africa. ${ }^{61}$

60. Humphrey, in E. Luard ed., supra note 5 , at 47.

61. Sohn, The Human Rights Law Of The Charter, 12 TEX. INT'L L.J. 129 (1977). H, LAUTERPACHT, supra note 5, at 159, argues that the Charter effects "a far-reaching change in the position of the individual in international law" by recognizing in "an international treaty of wide generality" the "rights of the individual as such." Given the ambiguous status of most international human rights instruments, the legal effect of the Charter, despite its weaknesses in drafting, is a question of some importance. H. KELSEN, THE LAW OF UNITED NAtions 29 (1950) argues that "the Charter does not impose upon the members a strict obligation to grant to their subjects the rights and freedoms mentioned in the Preamble or in the text of the Charter." The Charter's language, rather than being couched in precise legalistic terms, is characterized by a "lack of definiteness and definition" and by "hortatory phrases." Henkin, The United Nations and Human Rights, 19 INT'L ORG. 504, 510 (1965). M. Moskowitz, Human Rights and World Order 31, 32 (1959) suggests that the Charter is not in itself a source of legal obligations in reference to human rights. Moskowitz bases his arguments on the fact that U.N. intervention to enforce human rights is limited to action taken to meet a "threat to the peace" or a "breach of the peace" under Chapter VII. Otherwise, U.N. action in support of human rights is limited to "promotion and encouragement of human rights." In effect, Moskowitz concludes that there is, "no power other than that of international public opinion or example which can require a Member State to adopt any particular program for the promotion of human rights." In contrast, Sohn, id. at 131-32, contends that "The Charter is the cornerstone of international jus cogens, and its provisions prevail over all other international and domestic legislative acts. Should a state conclude a treaty or issue a legislative act or regulation which constitutes a gross violation of human rights, such a treaty or act would be clearly invalid as contrary to a basic and overriding norm of the Charter, and any Tribunal, international or domestic, which might be asked to apply such a treaty, act or regulation, should refuse to do so." H. LAUTERPACHT, supra note 5, at 145-47 agrees with Moskowitz that the U.N. Charter fails to provide machinery to implement the Charter's human rights clauses, but still maintains that the Charter imposes legally binding obligations.

In so far as such protection signifies the safeguarding of human rights and fundamental freedoms through a legally authorised and effective machinery of compulsion, it would seem that the authors of the Charter rejected the idea of a guarantee thus conceived.

He observes that the proposal that the Charter should ensure not only the "promotion," but also the "protection" of human rights and fundamental freedoms was rejected on the 


\section{B. The Universal Declaration of Human Rights}

United Nations organs took preliminary steps toward the drafting of a "bill of rights" prior to the ratification of the United Nations Charter. The Preparatory Commission of the United Nations, ${ }^{62}$ and its Executive Committee, ${ }^{63}$ recommended that the work of the Commission on Human Rights should be directed to the formulation of an international bill of rights. In its first session the General Assembly concurred in the Executive Committee's recommendation of Resolution 7(1). The General Assembly's directive was then incorporated by the Economic and Social Council into the terms of reference of the Commission on Human Rights. ${ }^{64}$

grounds that it "might be interpreted as giving the United Nations the right to impose actively upon the Members the observance of human rights and freedoms. . . ." After reviewing the Charter provisions, Lauterpacht observes that the restraint exhibited by these provisions,

Studiously falling short of conferment of direct executive authority, is impressive in its consistency. This caution is made more conspicuous by the choice of the agencies entrusted with the implementation, such as it is, of the provisions of the Charter. These agencies are the General Assembly and the Economic and Social Council. By the terms of the Charter both these organs are deprived of executive and legislative powers of binding decision. The only organ of the United Nations which is endowed with that power to a high degree, namely, the Security Council has no ordinary jurisdiction in the matter of human rights . . . .

Despite these "loose protections," H. LAUTER PaChT, $i d$. at 148, argues that the "cumulative legal result of all these pronouncements cannot be ignored." The fact that there is no definition or implementation of human rights is not controlling, "[for] the Charter fails to provide for the enforcement of its other numerous obligations the legal character of which is undoubted." The fact that human rights are not defined, results in a "diminished effectiveness" for the U.N. Charter rather than the protections being "destroyed," id. at 148-49. Lauterpacht goes on to support his argument by reference to the mandatory language of the human rights provisions in the Charter.

There is a mandatory obligation implied in the provision of Article 55 that the United Nations shall promote respect for, and observance of human rights and fundamental freedoms; or, in the terms of Article 13, that the Assembly shall make recommendations for the purpose of assisting in the realisation of human rights and freedoms. There is a distinct element of legal duty in the undertaking expressed in Article 56 in which 'all members pledge themselves to take joint and separate action in cooperation with the organisation for the achievement of the purposes set forth in Article 55.'

Id. at 148. A legal obligation placed upon the United Nations:

is an inescapable princple of interpretation that whenever an international instrument defines in its constitution, the purposes of its being, the right and obligation to give effect to those purposes are inherent in it and nothing short of an express derogation from that implicit authority can legitimately restrict the powers and obligations in question.

Id. at 159 .

62. Report of the Preparatory Commission of the United Nations (PC/20) Chap. III, Section 4, paras. 15-16.

63. Executive Committee Report on Committees and Commissions of the Economic and Social Council (PC/EX/95, section B, para. 21, p. 18).

64. G.A. Res. 7(I), January 29, 1946; ECOSOC Res. 5(I) of February 16, 1946. 
At its first meeting on January 27, 1947, the Human Rights Commission undertook the preparation of a bill of rights as its principal task. ${ }^{65}$ The first draft was to be prepared by the Commission's Bureau, consisting of its chairman (Mrs. Eleanor Roosevelt, United States), the Vice-Chairman and the rapporteur. The $\mathrm{Bu}$ reau used drafts prepared by the Director of the Division of Human Rights and by Great Britain as the basis of its discussion. ${ }^{66}$ The draft was submitted to the General Assembly on September 21, 1948. ${ }^{67}$

The General Assembly referred the draft to its Third Committee, which devoted eighty-one meetings to a discussion of the text. The Committee proposed one hundred sixty-eight formal amendments and "the text which finally emerged was surprisingly like the one that had been prepared by the Commission on Human Rights." ${ }^{28}$ The General Assembly acted quickly, and after adopting a United Kingdom amendment to Article 2, unanimously accepted the Declaration as resolution $217 \mathrm{~A}(111)$ on the night of December 10, $1948 .{ }^{69}$ The document was proclaimed by the

65. The Commission was charged with submitting proposals, recommendations and reports to the Council concerning: (a) an international bill of rights; (b) international declarations or conventions on Civil Liberties, the States of Women, Freedom of Information, and similar matters; (c) the protection of minorities; (d) the prevention of discrimination on grounds of race, sex, language or religion.

66. H. LAUTERPACHT, supra note 5, at 274; Humphrey, in E. Luard ed., supra note 5, at 48.

67. The Soviet Union attacked the drafting committee as "unrepresentative" and Mrs. Roosevelt reconstituted the Committee to include Australia, Chile, China, the United States, France, Lebanon, the United Kingdom and the Soviet Union. Humphrey, in E. Luard ed., supra note 5, at 48 . Initially the Commission was unable to produce a draft owing to differences of opinion over whether the bill of rights ought to be a non-binding declaration of principles or a binding international instrument. This disagreement was solved by initially adopting a declaration which would be non-binding, see Report of the drafting Committee Doc. E/CN.4/21. The Drafting Committee report was considered by the Commission in December 1947. The Commission decided to prepare both a non-binding declaration and a binding Covenant. In addition, a Working Group on Implementation was established in order to study methods of giving effect to international human rights guarantees, the Commission provisionally adopted drafts of a declaration and a Covenant for submission to the Economic and Social Council while the report of the Working Group was reserved for further study. The draft articles for an international declaration of human rights and for an international covenant on human rights and the report of the Working Group of Implementation are contained in Doc. E/800 and in Economic and Social Council, Official Records, Third Year, Sixth Session, Supp. No. 1 (1948). The Economic and Social Council did not have time to examine either the Draft Declaration or the Covenant, but decided to submit the Draft Declaration in the next session of the General Assembly in Paris. H. LAUTERPACHT, supra note 5, at 276.

68. Humphrey, in E. Luard ed., supra note 5, at 48.

69. Res. 217(111) in General Assembly, 3rd Session, Official Records Pt. I, Resolutions, p. 71; see also Universal Declaration of Human Rights, AM. J. INT'L L. Supp. 127 (1949). 


\section{General Assembly ${ }^{70}$}

as a common standard of achievement for all people and all $\mathrm{Na}$ tions, to the end that every individual and every organ of society, keeping this Declaration constantly in mind, shall strive by teaching and education to promote respect for these rights and freedoms and by progressive measures, national and international, to secure their universal and effective recognition and observance, both among the peoples of member states and among the peoples of territories under their jurisdiction.

The Preamble of the Universal Declaration of Human Rights states, inter alia, that "recognition of the inherent dignity and of the equal and inalienable rights of all members of the human family is the foundation of freedom, justice and peace in the world." The Preamble adds that, "Member States have, in joining the United Nations pledged themselves to achieve in cooperation with the United Nations, the promotion of universal respect for and observance of human rights and fundamental freedoms."71 "[I]t is essential, if man is not to be compelled to have recourse, as a last resort, to rebellion against tyranny and oppression, that human rights should be protected by the rule of law." 72 Finally, the Preamble concludes that a "common understanding of these rights and freedoms is of the greatest importance for the full realization of this pledge."73

The "rights" enumerated in the Declaration which belong to "everyone," or to "all human beings" or to "men and women of full age" have been called "most comprehensive."74

They include, among many items, not only provision for equality of treatment with respect to all rights and freedoms set forth in the Declaration, 'without distinction of any kind, such as race, colour, sex, language, religion, political or other opinion, national or social origin, property, birth or other status,' and the traditional personal liberties such as freedom and security of person, right to a fair trial, and freedom of thought, expression, opinion, religion, assembly, association and movement, but also

The vote was 48 in favor, 0 votes against, eight abstentions and 2 were absent. One of the absent countries subsequently informed the Secretary-General that if its representative had not been prevented from attending the meeting, the delegate would have voted for the Declaration. Doc. A/1311 of 7 August 1950. The dissenting votes came from the Soviet Union, five Eastern, Communist bloc countries, Saudi Arabia and South Africa.

70. Universal Declaration of Human Rights, id.

71. Id. at Preamble.

72. Id.

73. Id.

74. McDougal and Bebr, supra note 48 , at 614. 
certain more recently emerging political, economic and social claims, such as those to nationality and freedom to change nationality, to asylum from persecution, to take part in government and to have equal access to public service, to social security and choice of employment, and to education, leisure, participation in cultural life, and an adequate standard of living. ${ }^{75}$

The enthusiastic reaction to passage of the Declaration was typified by the reaction of Mrs. Eleanor Roosevelt who saw the document as embodying a world standard of individual human rights. "It might well become the Magna Carta of all mankind. . . . [I]t has importance comparable to the 1879 proclamation of the Declaration of the Rights of Man, the Declaration of Independence, and similar declarations made in other countries." 76

Other commentators familiar with the political divisions in the United Nations viewed the swift passage of the Declaration as a remarkable achievement. "[T]he adoption of the Declaration was probably the major achievement of the United Nations."

In less than two years, the organization had been able to agree on the adoption of a text in a matter which was not only rife with difficulties but which went to the very heart of the ideological conflict which had bedevilled the United Nations ever since San Francisco and is still largely responsible for preventing the organization from carrying out the major functions with which it is charged by the Charter. ${ }^{77}$

Although the Universal Declaration is formally a non-binding Declaration, it has served as the foundation for United Nations human rights activities. ${ }^{78}$ The provisions of the Declaration have served as a basis for various actions taken by the United Nations. The Declaration has inspired a number of international conventions both within and without the United Nations; exercised a significant influence on national constitutions and municipal legislation and, in several cases, has been influential in court decisions. The text of the provisions of the Declaration have been used

75. Id.

76. General Assembly Official Records, 3rd Session, Pt. I (1948) at 262. Morris B. Abram, New York Times, May 25, 1969 \& 6 (Magazine), at 117; and Pierre Juvigny of the French Conseil d'E' TAT, U.N. Secretariat, International Year for Human Rights. Newsletter No. 8, Supp. No. 1, at 18 (1966), both point out that the Universal Declaration is unique in having combined both civil, economic and social rights in the same instrument.

77. Humphrey, in E. Luard ed., supra note 5, at 49, citing L.M. GoOdrich, THE UNITED Nations 324 (1959). The swift passage may have been due to the Declarations nonbinding character.

78. Humphrey, in E. Luard ed., supra note 5, at 51. 
in international instruments of national legislation. ${ }^{79}$ There are also many instances of the use of the Declaration as a code of conduct or yardstick to measure the degree of respect for and compliance with the international standards of human rights. ${ }^{80}$

The Declaration itself has an ambiguous legal status. Ezejiofor points out that a "declaration" is not a formally binding instrument, and that states voting for the Universal Declaration made it clear that they did not intend to be legally bound by the Declaration. ${ }^{81}$ Lauterpacht, after analyzing the General Assembly debate, concluded that

[t]hey did so, to a large extent, in order to draw attention to the necessity of the Declaration being followed by a legally binding instrument-a Covenant-provided with means of international supervision and enforcement. . . ${ }^{82}$

It was only occasionally and by way of rare exception that a delegation showed some lack of appreciation of the fact that the Declaration was not intended to be legally binding. ${ }^{83}$

79. United Nations and Human Rights, supra note 3, at 9.

80. Id. For a comprehensive survey of human rights efforts inspired by the Universal Declaration of Human Rights see id. at 11-15, 25-29.

81. G. EZEJIOFOR, supra note 7, at 59. The U.N. Office of Legal Affairs has clarified the Legal Status of a "declaration."

In the United Nations practice, a 'declaration' is a formal and solemn instrument, suitable for rare occasions when principles of great and lasting importance are being enunciated, such as the Declaration on Human Rights. A recommendation is less formal.

A 'declaration' or a 'recommendation' is adopted by a resolution of a United $\mathrm{Na}$ tions Organ. As such it cannot be made binding upon Member States, in the sense that a treaty or convention is binding upon the parties to it, purely by the device of terming it a 'declaration' rather than a 'recommendation.' However, in view of the greater solemnity and significance of a 'declaration,' it may be considered to impart, on behalf of the organ adopting it, a strong expectation that Members of the international communty will abide by it. Consequently, in so far as the expectation is gradually justified by State practice, a declaration may by custom become recognized as laying down rules binding upon States.

U.N. Doc. E/CN.4/L.610 (1962). J. CAREY, supra note 5, at 9, seems to adopt this analysis in arguing that the Universal Declaration has a "quasi-legal" status. U. Thant referred to the Declaration as "norm-setting." Id

82. H. LAUTERPACHT, supra note 5, at 400 . A full discussion of the question of the legal status Declarations is contained in $i d$. at $397-408$.

83. Id. at 404. This view was limited to France, China and Belgium. The remarks of Mrs. Roosevelt are often quoted in support of the position that the Declaration has no legal status:

It is not a treaty; it is not an international agreement. It is not and does not purport to be a statement of law or of legal obligation. It is a declaration of basic principles of human rights and freedoms . . . to serve as a common standard of achievement for all peoples of all nations.

19 Dept. State Bull. 751 (1948). For the statement of other representatives, See The United Nations and Human Rights: Eighteenth Report of the Commission to Study the Organization for Peace (1968). Humphrey, in E. Luard ed., supra note 5, at 50, points out that the General Assembly had given the Commission a mandate to draft a convention covering the same 
Conversely, Sohn argues that the Universal Declaration is "part of the constitutional law of the world community and . . . has achieved the character of a world law superior to all other international instruments and to domestic laws."84 Sohn's view is bolstered by the 1968 Teheran Conference which unanimously proclaimed that the Declaration "states a common understanding of the peoples of the world concerning the inalienable and inviolable rights of all members of the human family and constitutes an obligation for the members of the international community." 85

Additional arguments favoring the legally binding status of the Declaration are contained in the Declaration on the Granting of Independence to Colonial Countries and Peoples, ${ }^{86}$ and in the Declaration on the Elimination of all Forms of Discrimination, ${ }^{87}$ which were both unanimously adopted by the General Assembly. These declarations provide that all states shall "observe faithfully and strictly the provisions of . . . the Universal Declaration of Human

rights covered in the declaration. Thus, if the declaration was intended to be binding, the Covenant would be duplicative and serve no purpose.

84. Sohn, The Universal Declaration of Human Rights, 8 J. INT'L COMP. JUR. 17, 26 (1967). See also E. Schwelb, Human Rights and the International Community (1964).

85. Final Act of the International Conference on Human Rights, U.N. Doc. A/ Conf.32/41, at 4, para. 2 (1968), See also Statement of the Unofficial Montreal Assembly for Human Rights which states that the "Universal Declaration of Human Rights constitutes an authoritative interpretation of the Charter of the highest order, and has over the years become a part of customary law." See J. CareY, supra note 5, at 13-14 nn. 18-19.

See also Statement of the United Nations Secretary-General in the Proclamation of the Final Act of the International Conference on Human Rights at Teheran, U.N. Doc. A/720/ Add.l (1968), at 13, ". . . the declaration not only constitutes an authoritative interpretation of the Charter obligations but also a binding instrument in its own right, representing the consensus of the international community on the human rights which each of its members must respect, promote and observe." Compare these statements with a resolution adopted unanimously by a Working Session of the World Peace Through Law Centre at Geneva in September 1968. See World Peace Through Law Centre, "The International Observance, World Law Day Human Rights 1968," Pamphlet Series No. 12, at 34 (1969). The session, "resolved to note that the Universal Declaration of Human Rights is in fact not part of the International Law of Nations in spite of its ratification by the General Assembly of the United Nations, and to reaffirm that all nations should consider the Declaration as a legal guide and that they have a moral responsibility to recognize its provisions, be they personal, political, economic or social, and to implement them, where appropriate, by just national legislation or administrative measures." Brierly attempts an interesting compromise between these two positions. J. Brierly, THE LAw OF NATIONS 293 (6th ed. 1963). Brierly argues that the Charter only contains a "pious injunction to co-operate in promoting respect of human rights. . . ." But a "pledge to cooperate . . . implies a negative obligation not so to act as to undermine human rights. . . "Thus, the Charter, in Brierly's view, imposes a negative duty on states.

86. G.A. RES. 1514 (XV), 15 U.N. GAOR, SUPP. (16) 66-67, U.N. DOC. A/4694 (1960).

87. The United Nations and Human Rights, U.N. Doc. OPI/621 (1978) 87. 
Rights. . . ."88 Additional evidence supporting the legally binding nature of the Declaration can be found in Economic and Social Council Resolution 1503, which confers upon a Subcommission the authority to consider petitions which "appear to reveal a consistent pattern of gross and reliably attested to violations of human rights and fundamental freedoms." Under the interpretation given to Resolution 1503, the Universal Declaration of Human Rights is considered one of several authoritative statements of human rights, the violation of which provides a basis for complaints. ${ }^{89}$

\section{The Civil and Political Covenant}

The General Assembly determined that the international "Bill of Rights" should consist not only of a Declaration, but also of a covenant and measures of implementation. ${ }^{90}$ The General Assembly subsequently decided that there should be two covenants-one covering civil and political rights, and the other covering economic and social rights - and that the measures of implementation should be contained in the covenants. ${ }^{91}$ However, in 1966 it was decided

88. See note 86, supra; G.A. Res. 1904 (XVIII), Art. 2, 18 U.N. GAOR, SUPP. (15) 3537, U.N. Doc. A/5515 (1963).

89. ECOSOC RES. 1503 (XLVIII) May 27, 1970. Guggenheim, Key Provisions of the New United Nations Rules Dealing With Human Rights Petitions, 6 N.Y.U.J. INT'L L. \& POL'y 427, 435 (1973). Further discussion of the Declaration are contained in N. RoBINSON, The Universal Declaration of Human Rights: Its Origin, Significance, ApplicaTION AND INTER PRETATION (1958); E. SCHWELB, HUMAN RIGHTS AND THE INTERNATIONAL Community: The Roots and Growth of the Universal Declaration of Human Rights 1948-1963 (1965); L.B. Sohn, A Short History of United Nations Documents on Human Rights, Commission to Study the Organization of Peace, The United Nations and Human Rights (18th report of the Commission, 1968); S. Rabanbeln, A Muslim Commentary on the Universal Declaration of Human Rights (1970); Verdoot, The Present Significance of the Universal Declaration of Human Rights, 7 WORLD JUSTICE 158-69 (1965).

90. Report of the Commission on Human Rights, Second Session, Economic and Social Council Office Records Supplement No. 1 (E/600), para. 18, December 2 to 17, 1947; G.A. Resolutions 217F (III), December 10, 1948; 421E (V), December 4, 1950; 543 (VI), February 5,1952 . Initially it was thought that only civil and political rights should be protected, but the majority of the General Assembly declared at its fifth session, in 1950, that the enjoyment of civil and political freedoms and economic, social and cultural rights "are interconnected and interdependent" and instructed the Commission on Human Rights to include in the Draft Covenant, "a clear expression of economic, social and cultural rights in a manner which relates them to the civil and political freedoms proclaimed by the draft covenant." G.A. REs. 421E (V), December 4, 1950. In 1952 the General Assembly decided that two covenants should be drafted, simultaneously approved, and opened for signature. G.A. RES. 543 (VI), February 5, 1952. It should be noted that the preamble of each of the covenants recognizes that the "ideal of free human beings . . can only be achieved if conditions are created whereby everyone may enjoy the economic, social and cultural rights, as well as his civil and political rights."

91. Schwelb, Some Aspects of the International Covenants on Human Rights of December 
that an individual's right to petition should be included in a separate Optional Protocol attached to the International Covenant on Civil and Political Rights.

The Human Rights Commission devoted six sessions between 1949 and 1954 to preparing the draft covenants. ${ }^{92}$ In 1954 the draft covenants were submitted to the General Assembly, which subsequently devoted twelve years to an article by article consideration of the draft covenant. ${ }^{93}$ On December 16, 1966, eight years after the adoption of the Universal Declaration of Human Rights, ${ }^{94}$ the International Covenant on Civil and Political Rights, the Optional Protocol, and the International Covenant on Economic Social and Cultural Rights were adopted and opened for signature, ratification and accession. ${ }^{95}$

Sohn evaluated the significance of the fifty-three articles of the International Covenant on Civil and Political Rights.

For the first time, the international community reached an agreement not only on the list of basic human rights, but also on the content of each right and on the most important limitations to such rights. ... [they are] more precise, providing detailed guidelines for the conduct of governments, specific legal protections for individuals, and an enumeration of instances in which public safety, order health, morals, etc. can be invoked to limit individual freedoms. Secondly, the Covenants contain various measures of implementation; though some of them are optional

1966, in A. Eide and A. Schou eds., supra note 5, at 103. Although suggestions were made to reconsider the decision to have one covenant, the subject was not reopened formally since a great deal of delay would have resulted. See Schwelb, id. at 106 citing U.N. Doc. A/C.33/ SR.1396 (October 17, 1966) (Sudan). See also Starr, International Protection of Human Rights and the United Nations Covenants, 1967 WIS. L. Rev. 863, 864 n.4. Schwelb, supra at 106 states that the decision "for two instruments can be explained by the . . . fundamental different character of the rights concerned."

92. Starr, supra note 91 , at 864 n.4.

93. Id.

94. G.A. REs. 217, (III), December 10, 1948.

95. U.N. Doc. A/PV.1496, Provisional. The voting was unanimously in favor of both the International Covenant on Economic, Social and Cultural Rights (105-0) and of the Civil and Political Covenant (106-0) with a majority in favor of the optional protocol (66 in favor, 0 opposed and 38 abstentions). Australia signed the Covenant on Political and Civil Rights on December 18, 1972; the United States signed the Covenant on October 5, 1977. Neither country has taken the legislative action required to ratify the Covenant. Schwelb, supra note 91, at 123, remarks that the impetus gained from passage of the Convention on the Elimination of All Forms of Racial Discrimination was responsible for passage of the International Convention on Civil and Political Rights. Useful discussions of the Covenants can be found in M. Ganjl, supra note 5; T. Green, The United Nations and Human Rights 37-67 (1956); E. Schwelb, Human Rights and the International Community (1964); MacChesney, International Protection of Human Rights in the United Nations, 47 Nw. U.L. REV. 198 (1952); Starr, supra note 91, at 864. 
in character, they recognize the right of individuals to seek redress of their grievance on the international plane . . . . [it is an] authoritative interpretation of the basic rules of international law on the subject of human rights which are embodied in the Charter. .. 96

The States legal obligations under the Covenant are set forth in Article 2(1) whereby each party to the Covenant undertakes to "respect and to ensure to all individuals within its territory and subject to its jurisdiction the rights recognized in the present Covenant without distinction of any kind. ..." Under Article 2(2) each Party "undertakes to take the necessary steps . . . to give effect to the rights recognized in the present Covenant" where a right is not already protected by existing legislation.

The rights recognized in the Covenant include:

[A] right to life; prohibitions on torture and slavery; liberty and security of the person including protection from arbitrary arrest or detention; humane treatment of persons in prison; liberty of movement and ... freedom to leave any country, including one's own and a right to enter one's own country; equality before the law; fair and public trials with various guarantees, such as right to counsel, a privilege against self-incrimination . . . and a prohibition against ex post facto laws; freedom of religion; freedom of expression; a right of peaceful assembly; and freedom of association. ${ }^{97}$

1. Limitations. Robertson makes two general observations concerning the rights afforded individuals under the Covenant. ${ }^{98}$ First, the "definitions given are frequently more liberal or progressive" than in other comparable instruments. ${ }^{99}$ Further, the rights

96. Sohn, supra note 43 , at 135 . Sohn comments that since the Covenant was adopted unanimously by 105 votes to 0 and the Universal Declaration by 50 votes to 0 , that the Covenant "is even more universal in their origin than the declaration." Id. at 136.

97. Starr, supra note 91, at 867 . Robertson lists rights which are in the Covenant which do not appear in the Universal Declaration of Human Rights: the right of detained persons to be treated with humanity; freedom from imprisonment for debt; prohibition of propaganda for war and of incitment to hatred; the rights of the child; and the rights of minorities. The right to property is contained in the Universal Declaration but excluded from the Covenant On Civil and Political Rights, A. Robertson, supra note 5, at 37.

98. Id.

99. Id. See article on the right to life "which, although not prohibiting the death penalty," clearly is "drafted with the intention of indicating that it should be abolished." Article 10 provides that all detained persons, "shall be treated humanely and with respect for the inherent dignity of the human person"; separate facilities are to be provided for juveniles and adult offenders; and that the "essential aim" of the penitentiary system shall be the "reformation and social rehabilitation of prisoners." Article 14 guarantees defendants certain rights at trial - an independent, impartial tribunal, a public hearing, presumption of 
enumerated in the Covenant are "so general or imprecise that the texts appear to be more statements of political principle or policy than of legally enforceable rights." 100 The drafting tends to be so broad as to be either unrealistic, unenforceable or providing decision-makers with almost unlimited discretion. Examples of such broad statements include Article 10(3) establishing "reformation and social rehabilitation" as "essential aims" of the penitentiary system; Article 16 requiring the "right to recognition everywhere as a person before the law;" the prohibition in Article 20 of "propaganda for war;" and Article 25(a) guaranteeing everyone the right to take part in the "conduct of public affairs."101

Another problem presented by the drafting of the rights in the Covenant involves the subjucation of certain rights to those restrictions which are proscribed by law. Included are those items necessary to protect public safety, order, health, morals or the fundamental rights and freedoms of others, ${ }^{102}$ or those which are necessary for national security in a democratic society. ${ }^{103}$ These limiting clauses have potentially far-reaching limitations on human rights protection under the Covenant. For example, Schwelb discusses the possible limitations of rights by the application of the "public order" exception. "The delegations responsible for this formula were not willing to admit to their public that freedom of the press, of assembly and association are limited by whatever public policy prevails in a State Party and one chose therefore the presumably less embarrassing French term." 104 Schwelb goes on to argue that the "public order" limitation implies that if, for example, South Africa became a State Party to the Covenant, such rights as freedom of the press, assembly and association could all be limited by the requirements of South Africa's apartheid policy; ${ }^{105}$ its ordre public.

Another limitation on the scope of the rights contained in the International Covenant on Civil and Political Rights is found in Article 4. Article 4 authorizes States to take measures derogating

innocence and protection against self-incrimination, right of appeal, compensation for a miscarriage of justice, and the principle of ne bis in idem.

100. Id. at 38.

101. International Covenant on Civil and Political Rights U.N. OPI/562 (1976). [hereinafter cited as Civil and Political Covenant].

102. Id. Part II, art. 18(3) (right of thought conscience, and religion).

103. See id. art. 21 (right of assembly), art. 12 (right of internal movement), art. 22(2) (right to form and join unions), art. 19(3)(a)(b) (right of expression).

104. Schwelb, supra note 91 , at 115.

105. Id. 
from their obligations under the Covenant in time of "public emergency which threatens the life of the Nations, the existence of which is officially proclaimed." State Parties will be allowed to vary from the protections of Article 4 only under a series of narrow conditions and limitations. ${ }^{106}$

A further limitation on the scope of human rights protections in the Covenant on Civil and Political Rights is found in Article 5. Article 5 stipulates that "[n]othing in the the present Covenant may be interpreted as implying for any State, group or person any right to engage in any activity aimed at the destruction of any of the

106. See Civil and Political Covenant, supra note 101, art. 4(1)(2)(3). See also Publications of the European Court of Human Rights, Series B. Lawless Case (hearing of April 8, 1961); for ruling of the European Court, Lawless Case (Merits), Judgment of July 1, 1961, para. 22, reprinted in [1961] Y.B. Eur. Conv. on Human Rights No. 4, 438, at 472 (Eur. Comm. of Human Rights). Both the European Commission and Court of Human Rights take the position that it was their task to determine whether the conditions for exercise of a similar right of derogation had been fulfilled and whether the exceptional measures did not exceed the extent strictly required by the situation.

The narrow conditions and limitations to which derogation under Article 4 is subject to include:

(a) the public emergency must threaten the life of the nations;

(b) its existence must be officially proclaimed;

(c) the emergency measures must not go beyond what is strictly required by the exigencies of the situation;

(d) the emergency measures must not be inconsistent with the State Party's other obligations under international law;

(e) they must not involve discrimination solely on the grounds of race, color, sex, language, religion, or social origin;

(f) no derogation is permitted from the protections of Article 6 (right to life), Article 7 (freedom from torture), Article 8(1)(2) (freedom from slavery), Article 11 (prohibition of imprisonment for debt), Article 15 (prohibition of conviction for an act which was not a crime when it was committed), Article 16 (recognition as a person before the law) and from Article 18 (freedom of religion);

(g) and a State availing itself of the right of derogation shall immediately inform the other States Parties of the provisions from which it has derogated and of the reasons 'by which it was actuated.'

The European Convention under Article 15 permits derogation from obligations under the European Convention in time of "war" as well as in time of "other public emergency." No derogation is permitted from Article 2 (right to life); Article 3 (right to be free from torture or inhuman or degrading treatment of punishment); Article 4(1) (right to be free from slavery); and Article 7 (right to be free from punishment for an act which was not a crime at the time the act was committed).

The American Convention on Human Rights, Article 27, permits derogation from the rights protected in the Convention in "time of war, public danger, or other emergency that threatens the independence or security of a State Party." Under Article 27(2) no derogation is permitted from Article 17 (rights of the family); Article 18 (right to a name); Article 19 (rights of the child); Article 20 (right to a nationality); Article 23 (right to participate in government).

Article 27(3) of the American Convention on Human Rights requires that State Parties not only must inform other States Parties of derogation of rights in the Convention in "time of war, public danger, or other emergency that threatens the independence or security of a State Party," but that such State Parties must set a date for "termination of such suspension." 
rights and freedoms recognized herein." A broad interpretation of this clause might be used to justify a restraint of individuals engaged in "any activity" allegedly aimed at "the destruction of any of the rights and freedoms" recognized in the Covenant. This provision might be misused to limit the otherwise lawful activity of individuals or groups perceived by a government as being unduly critical of government policies or as creating social unrest. ${ }^{107}$

Another major limitation on the scope of human rights protection in the International Covenant on Civil and Political Rights is Article 2(1) under which "[e]ach State Party . . . undertakes to respect and to ensure to all individuals within its territory and subject to its jurisdiction the rights recognized in the present Covenent." In contrast, Article 1 of the European Convention on Human Rights obligates State Parties to secure rights to "everyone within their jurisdiction," and Article 1 of the American Covention on Human Rights obligates States to ensure rights to all persons "subject to their jurisdiction."

Arguably the limiting language "within its jurisdiction" in Article 2(1) of the Covenant may be interpreted so as to relieve State Parties of responsibility for human rights violations perpetrated against individuals outside their territory. ${ }^{108}$ The concept of "state action" should not only be applied extraterritorially, but arguably, should also be broadened to impose liability on States Parties for human rights violations perpetrated by corporations chartered by States Parties but operating outside the jurisdiction, and activities of quasi-governmental vigilante-type groups operating outside the States' borders. ${ }^{109}$

107. The language of Article 17 of the European Convention is identical to that of Article 5 of the Covenant on Civil and Political Rights. Article 17 was the basis for the European Commission of Human Rights rejection in July 1957 of an application by the German Federal Constitutional Court of August 17, 1956, that had declared the Party illegal, dissolved it and confiscated its assets. The Commission determined that the declared aims of the Party, according to its own declarations, was to establish a Communist society by means of proletarian revolution and establish the dictatorship of the proletariat. The Commission found that "dictatorship" would be inconsistent with rights under the Convention and that the activities of the Party fell clearly within Article 17, Application 250/57, [1957] Y.B. EUR. Conv. ON Human Rights No. 1 222-225 (Eur. Comm. of Human Rights). Article 2a(a) of the American Convention of Human Rights does not permit any

.. group or person to suppress the enjoyment or exercise of the rights and freedoms recognized in this Convention or to restrict them to a greater extent than is provided for herein.

108. This might arise in the context of State security agencies engaged in harassment of the State's nationals living abroad.

109. For discussion of multi-national corporations, See United Nations, Multi-national Corporations in World Development U.N. Doc. ST/ECA/190 (1974) and The Impact of 
In addition to problems involving the drafting of the rights and the limitations on their scope, the Covenant may impose unrealistically strict legal obligations upon States Parties. Under Article 2(1) "each State Party undertakes to ensure to all individuals . . . the rights recognized in the present Covenant, without distinction"; and, under Article 2(2), where such rights are not provided for by existing laws, "each State Party ... undertakes to take the necessary steps . . . to give effect to the rights recognized in the present Covenant."110 Schwelb argues that States Parties are under "the obligation to maintain a defined standard." 111 This obligation is tempered by allowance for certain domestic limitations.

In contrast, Schwelb views the International Covenant on Economic and Social Rights as a "promotional Covenant," setting forth standards which States Parties pledge themselves to "secure progressively." 112 Under Article 2(1) of the International Covenant on Economic Social and Cultural Rights, each State Party undertakes "to take steps individually and through international assistance and cooperation . . . to the maximum of its available resources with a view to achieving progressively the full realization of the rights recognized in the present Covenent." 113

Thus, unlike the Civil and Political Covenant, the Social and Economic Covenant makes allowances for socioeconomic and technological barriers which may prevent States Parties from immedi-

Multi-national Corporations on Development and on International Relations, Report of the Group of Eminent Persons to Study the Impact of Multi-national Corporations on Development and on International Relations U.N. Doc. E/5500/Rev. 1, ST/ESA/6 (1974).

110. State Parties to the European Convention, under Article 1, "shall secure to everyone within their jurisdiction the rights and freedoms. . ." The American convention under Article 1 obligates State Parties to "undertake to respect the rights and freedoms recognized herein and to ensure . . . the free and full exercise of the rights protected in the Convention."

111. Schwelb, supra note 91 , at 108.

112. Id.

113. Other limitations on State Party responsibility under the International Covenant on Economic-Social and Cultural Rights include Article $\mathbf{4}$ which provides that

.. . State may subject such rights only to such limitations as are determined by law only so far as this may be compatible with the nature of these rights and solely for the purpose of promoting the general welfare in a democratic society.

A further limitation on state responsibility is contained in Article 2(3) which provides that developing countries, with due regard to human rights and their national economy, may determine to what extent they would guarantee the economic rights recognized in the present Covenant to non-nationals.

Starr, supra note 91 , at 869 , remarks that this latter provision runs counter to the Charter principle of sovereign equality of Member States, and it fails to take account of certain minimum standards that international law imposes on States with respect to treatment of aliens.

Furthermore, it is difficult to reconcile this provision with the spirit of universality and nondiscrimination of the Universal Declaration, embodied in the preceeding paragraph of the same Article of the Covenant. 
ately implementing the rights contained in the Covenant. ${ }^{114}$ Allowing States Parties to postpone or possibly avoid such "progressive implementation" of the Social and Economic Covenant, seems more realistic than does the requirement of the Civil and Political Covenant that States Parties maintain a "defined standard."115 The qualifications and difficulties involved in the draft-

114. Id.

115. At the same time, as of January 1978 , only slightly more states had signed the International Covenant on Economic, Social and Cultural Rights than had signed the International Covenant on Civil and Political Rights. The Former Covenant had 46 signatories (23 ratifications) and the Civil and Political Covenant 44 signatories (24 ratifications). See Amnesty International, International Bill of Human Rights 50 (1978).

There are two additional problems with human rights guarantees in the Covenant and two conceptual problems all of which should be mentioned. Under Article 50, the provisions of the Covenant are extended to constituent units of federal States (e.g. United States, Australia, Canada, India). This presents a problem since many of the human rights guarantees in the Covenant are within the constitutional powers of constituent units of federal States and implementation of such rights depends upon the initiative of the constituent units. See U.N. Doc. A/C.3/SR.1411 (1966); Report of the Third Committee A/6546, paras. 129-36; See also Proposed United States reservation to Article 14 "Message from the President of the United States Transmitting The International Covenant On Civil and Political Rights" 95th Congress 2nd Session, XIV, February 23, 1978. Secondly, according to Schwelb, supra note 91, at 113-14, the Commission on Human Rights was unable to agree on a clause on reservations. G.A. Res. 546 (VI), February 5, 1952. See Report of the Tenth Session of the Commission on Human Rights E/2573 (1974). The absence of a provision on reservation will, according to Schwelb, permit States to formulate reservations "not incompatible with the object and purpose of the treaty." Schwelb, supra note 91, at 114.

Acceptance by another contracting State of a reservation constitutes the reserving State a party to the treaty in relation to that State . . . If South Africa were to decide to ratify the Covenants subject to the reservation that it does not accept those of their provisions which prohibit discrimination and if one single other State Party were to accept this reservation, South Africa would become a party to the Covenants with all the prestige and Status this might imply.

Id. As suggested, there are two conceptual difficulties involved in the Covenant. See supra note 102, Part I, art. 1(1) (the same article appears in the Covenant On Economic, Social, and Cultural Rights) provides that, "all peoples have the right of self-determination by virtue of that right they freely determine their political status and freely pursue their economic, social and cultural development."

See General Assembly Resolution 545 (VI), February 5, 1952, for drafting of final text, General Assembly Official Records, 10th Session (1955), Annexes, Report of the Third Committee A/3077, paras. 27-77. The Third Committee adopted the Article by 33 votes to 12 with 13 abstentions. Article 1(3) provides that "the States Parties, including those having responsibility for the administration of Non-Self-Governing and Trust Territories, shall promote the realization of the right of self-determination, and shall respect that right. . . " The inclusion of these two ambiguous, collective rights may be inappropriate in a Covenant addressing individual human rights. Another conceptual problem involves Article 1(2) of both the Civil and Political Covenant and the Economic and Social Covenant; and Article 47 of the Civil and Political Covenant and Article 25 of the Economic and Social Covenant. Article 47 provides that, "nothing in the present Covenant shall be interpreted as impairing the inherent right of all peoples to enjoy and utilize fully and freely their natural wealth and resources." This collective right also seems conceptually distinct from the individual rights enumerated in the Covenant On Civil and Political Rights. 
ing of the Civil and Political Covenant raises the question of whether the Covenant might more accurately be characterized as providing for "human privileges" rather than for "human rights."

\section{Implementation of the Covenant on Civil and Political} Rights. The draft provisions on implementation were prepared by the Commission on Human Rights between 1947 and $1954 .{ }^{116} \mathrm{Be}-$ tween 1945 and 1966 the substantive provisions of the Covenant were under consideration by the General Assembly. ${ }^{117}$ As a result, the main committee of the General Assembly, the Third Committee, was not in a position to address itself to the measures of implementation until its 18 th session in 1963 , at which time only a general debate on the implementation provisions was conducted. ${ }^{118}$

The 19th session of the General Assembly in 1964 was devoted to a debate of Article 19 of the Charter, and at the 20th session in 1965, the General Assembly was involved in drafting and adopting the International Convention on the Elimination of All Forms of Racial Discrimination. ${ }^{19}$ Thus it was not until the 21 st session in

116. Commission on Human Rights, Report of the Tenth Session, 18 U.N. ESCOR, SupP. (No. 7), U.N. Doc. E/2573 (1954). At the request of the General Assembly, G.A. ReS. 833, 9 U.N. GAOR, SUPP. (No. 21) 20, U.N. Doc. A/2890 (1954), the Secretariat prepared the Annotations on the text of the Draft International Covenants on Human Rights, 10 U.N. GAOR, Annexes (Agenda Item 28, Part II) 1, 67 and 116, U.N. Doc. A/2929 (1955). Chapters VII and IX of which deal with the draft measures of implementation. At a later stage, again at the request of the General Assembly, G.A. REs. 1843B, 17 U.N. GAOR, SUPP. (No. 17) 35 U.N. Doc. A/5217 (1962), the Secretary General prepared an additional Explanatory paper on measures of implementation, 18 U.N. GAOR, 2 Annexes, Vol. 2 (Agenda Item 48), U.N. Doc. A/5411 (1963). Capotorti states that:

international measures of implementation is used to indicate, the collective legal instruments through which the States parties to a multilateral agreement, or the Organization which has promoted the stipulation of agreements among the Members, try to ensure the fulfillment of the obligations undertaken by each contracting State.

The most widely used measures of international implementation are - periodic reports, conciliation between States, and individual petition. Capotorti, The International Measures of Implementation Included in the Covenants on Human Rights, in A. Eide and A. Schou eds., supra note 5, at 131.

117. Schwelb, supra note 91, at 104-05.

118. See Report of the Third Committee, 18 U.N. GAOR, 2 Annexes (Agenda Item 48) 14, 23-25, paras. 109-124, U.N. Doc. A/5655 (1963) and summary records of the 1267th to 1269th and 1273rd to 1275th meetings of the Third Committee, 18 U.N. GAOR, C.3 (1267th mtg.) 287, U.N. Doc. A/C.3/SR.1267 (1963); (1268th meeting) 293, U.N. Doc. A/C.3/ SR. 1268 (1963); (1269th meeting) 299, U.N. Doc. A/C.3/SR.1269 (1963); (1273rd meeting) 327 U.N. Doc. A/C.3/SR.1273 (1963); (1274th meeting) 333, U.N. Doc. A/C.S/SR.1274 (1963); (1275th meeting) 341, U.N. Doc. A/C.3/SR.1275 (1963); (1267th meeting) 347, U.N. Doc. A/C.3/SR.1276 (1963). See also G.A. Res. 1960, 18 U.N. GAOR, SuPP. (No. 15) 42, U.N. Doc. A/5515 (1963).

119. Report of the Third Committee, 20 U.N. GAOR, 2 Annexes (Agenda Item 65) 10, 
1966 that the Third Committee initiated an article-by-article examination and drafting of the measures for implementation of the International Covenant on Civil and Political Rights and its accompanying Optional Protocol. The General Assembly approved the Covenant and the measures of implementation, along with the International Covenant on Economic, Social and Cultural Rights at its 1496th meeting on December 16, 1966. ${ }^{120}$

The draft measures of implementation of the Covenant on Civil and Political Rights were presented by the Commission on Human Rights in 1955. ${ }^{121}$ The measures provided that if a State Party believed that another State Party was not giving effect to a provision of the Covenant, it could refer the matter to the Human Rights Committee established under the Covenant. The Committee would then ascertain the facts, and make available its "good offices," with a view toward reaching a friendly settlement of the matter. If a solution was not reached, the Committee was to draw up a report, stating whether in its opinion the facts disclosed a breach of the state's obligations. The Human Rights Committee was to be composed of nationals of States Parties to the Covenant. They were to be elected by the International Court of Justice (I.C.J.), and were to serve in their "personal capacity." 122

The Commission's draft also provided that the I.C.J. might render an advisory opinion on any legal question before the Committee. In cases where the Human Rights Committee failed to reach a solution, recourse could be had to the I.C.J. ${ }^{123}$ and State Party reports. ${ }^{124}$ Proposals to grant a right of petition to individuals and nongovernmental organizations, or to vest in the Committee the ex officio power to consider interstate complaints of alleged

U.N. Doc. A/6173 (1965), and summary records of the 1370th and 1374th meetings of the Third Committee, 20 U.N. Doc. A/C.3/SR.1370 (1965) and (1374th meeting) 503, U.N. Doc. A/C.3/SR.1374 (1965). See also G.A. Res. 2080, 20 U.N. GAOR, SuPP. (No. 14), U.N. Doc. A/6014 (1965).

120. See Report of the Third Committee, 21 U.N. GAOR, 2 Annexes (Agenda Item 62) 7, U.N. Doc. A/6546 (1966) and 21 U.N. GAOR (1496th Plen. Meeting) 1-14, U.N. Doc. A/ PV. 146 (1966). The implementation measures are discussed in, Buergenthal, Implementing the U.N. Racial Convention, 12 TEX. INT'L L.J. 187 (1977). Capotorti, supra note 116; Schwelb, Civil and Political Rights: The International Measures of Implementation, 62 AM. J. INT'L L. 827 (1968); Schwelb, The International Measures of Implementation of the International Covenant on Civil and Political Rights and of the Optional Protocol, 12 TEX. INT'L L.J. 141 (1977).

121. Annotations, supra note 116 , draft art. 40 , at 81 and draft art. 43 , at 89 .

122. Id. draft art. 27 , at 68 .

123. Id draft art. 44 , at 91 .

124. Id draft art. 48 , at 95 and draft art. 49 , at 100. 
human rights violations, were narrowly rejected at successive sessions of the Commission on Human Rights. ${ }^{125}$

The General Assembly debate on the proposed implementation provisions of the International Covenant on Civil and Political Rights was characterized by an ideological split between the Soviet Union and the United States. ${ }^{126}$ The Soviet Union and other Communist nations opposed permitting interstate complaints on the grounds that it would unduly interfere in the domestic affairs of the state against whom the complaint had been lodged, contrary to Article 2(7) of the United Nations Charter. ${ }^{127}$ Consistent with Socialist philosophy, the Communist nations also argued that the implementation measures in the Civil and Political Covenant should be "no stronger" than those in the Economic and Social Covenant. ${ }^{128}$ The Romanian representative, Mr. Glazer, commented that "human rights could not be built upon the ruins of national independence." 129 In rebuttal, the Western representatives contended that the effectiveness of the Covenant depended upon strong implementation clauses. ${ }^{130}$

125. For a description of these attempts, see E. Schwelb, Notes on the Early Legislative History of the Measures of Implementation of the Covenant on Human Rights, in MeLANGES Modinos (1968).

126. By the time the General Assembly examined the provisions on implementation of the Covenant on Civil and Political Rights, liberal implementation measures had been incorporated in the International Covenant on the Elimination of all Forms of Racial Discrimination, G.A. Res. 2106A, 20 U.N. GAOR, SUPP. (No. 14), 47, U.N. Doc. A/6014.

127. See the Statements in the meeting of the Third Committee by the U.S.S.R. (Mr. Nasinovsky), 21 U.N. GAOR, C.3 (1397th meeting) 121-22, para. 48, U.N. Doc. A/C.3/ SR.1397 (1966) and $i d$. (1399th meeting) 127, paras. 22-24, U.N. Doc.A/C.3/SR.1399 (1966); Ukraine S.S.R. (Mr. Kornyenko), 21 U.N. GAOR, C.3 (1415th meeting) 220, paras. 8-11, U.N. Doc. A/C.3/SR.1415 (1966); Bulgaria (Mr. Bahnev), 21 U.N. GAOR, C.3 (1416th meeting) 226, paras. 7-11, U.N. Doc. A/C.3/SR.1416 (1966); Czechoslovakia (Mrs. Sekaninova-Cakrtova), id. at 228, paras. 222-25, Romania (Mr. Glazer), id. at 227, paras. 15-18, Hungary (Mr. Beck), 21 U.N. GAOR C.3 (1417th meeting) 237, para. 37, U.N. Doc. A/C.3/ SR 1417 (1966). The positions were the same in the general debate at the 18th Session of the General Assembly.

128. In the early years of discussion on implementation measures the Soviet Union opposed reporting procedures as being an interference with the sovereignty of states. Statement by the Soviet Delegation to the Commission on Human Rights, report of the Fifth Session, 9 U.N. ESCOR, Supp. (No. 10), Annex 111, 47-48, U.N. Doc. E/1371 (1949). See also Carey, Implementing Human Rights Conventions The Soviet View, 53 KENTUCKY L. REv. 114 (1964).

129. Mr. Glazer (Romania), 21 U.N. GAOR, C.3 (1416th meeting) 227, para. 16, U.N. Doc. A/C.3/SR.1416 (1966).

130. See Lady Gaitskell (U.K.), 21 U.N. GAOR, C.3 (1415th meeting) 222, para. 25, U.N. Doc. A/C.3/SR.1415 (1966); Mr. MacDonald (Canada), 21 U.N. GAOR, C.3 (1387th meeting) 62, para. 37, U.N. Doc. A/C.3/SR.1387 (1966); Mr. Mommersteeg (Netherlands), 21 U.N. GAOR, C.3 (1397th meeting) 119, para. 19, U.N. Doc. A/C.3/SR.1397, id. (1400th meeting) 132, para. 14, U.N. Doc. A/C.3/SR.1400 (1966). 
A compromise proposal termed an "original solution" was successfully proposed by the Afro-Asian delegations. ${ }^{131}$ The proposal attempted to provide strong implementation measures while also recognizing that "new countries" lacked the legislative infrastructure to implement rights immediately. The following four stage implementation process was viewed as necessary: ${ }^{132}$ (a) the creation of international machinery; (b) establishment of a reporting system; (c) provisions for interstate complaints and conciliation machinery, and (d) establishment of an international authority to receive and act upon complaints by individuals against their own or other states. The Indian delegate felt the "time was ripe" for the first two stages. ${ }^{133}$ This proposal was accepted, and became the basis for the implementation machinery of the Covenant on Civil and Political Rights.

\section{The Human Rights Committee}

The Human Rights Committee is the principle organ involved in implementing the International Covenant on Civil and Political Rights. ${ }^{134}$ Committee members are elected by the States Parties to the Covenant ${ }^{135}$ rather than by the I.C.J., as was originally provided in the Afro-Asian draft. Each State Party may nominate not more than two of its own nationals to serve on the eighteen member committee which is elected by secret ballot. ${ }^{136}$ The Committee may not include more than one national from each state. Nominees must be "persons of high moral character and recognized competence in the field of human rights, consideration being given to the usefulness of the participation of some persons having legal experience." ${ }^{137}$ In the election, consideration shall be given to the equitable geographic distribution of membership, to the representation of "different forms of civilization and of the principle legal sys-

131. Two virtually identical drafts were proposed. India, Iran, Libya, Nigeria, Pakistan, Senegal, Sudan, The United Arab Republic and Upper Volta sponsored U.N. Doc. A/C.3/ L.1379 and Rev. 1 (1966); and U.N. DoC. A/C.3/L.1373 (1966) was cosponsored by the same delegations together with those Mali, Mauritania, Senegal, Sierra Leone and Tunisia. [The documents will be hereinafter cited as the Afro-Asian Amendments].

132. Mr. Sanon (Upper Volta), 21 U.N. GAOR, C.3 (1418th meeting) 242, para. 12, U.N. Doc. A/C.3/SR.1418 (1966).

133. Mr. Sinha (India), 21 U.N. GAOR, C.3 (1416th meeting) 225, para. 1, U.N. Doc. A/C.3/SR.1418 (1966).

134. Civil and Political Covenant, supra note 101, art. 28.

135. Id. art. 29(1).

136. Id arts. $28(1), 29(1)$.

137. Id. art. 28(2). 
tems." 138

Individuals "serve in their personal capacity,"139 and in order to insulate them from political pressures, they serve a four year term. ${ }^{140}$ Further, they receive "emoluments" from United Nations resources rather than from their state of nationality. ${ }^{141}$ The independence of members of the Human Rights Committee, in the final analysis, is limited by the fact that they must be nominated and renominated by their State of nationality. ${ }^{142}$

The draft Covenant contained a provision, modeled after Article 31 of the Statute of the I.C.J., which provided that a State Party involved in a case being heard by the Human Rights Committee may, if none of its nationals is a member of the Committee, designate a person of its choice to participate and vote in the Committee deliberations. This provision was deleted at the 1951 session of the Commission on Human Rights because such ex officio representation was thought to interfere with the neutrality of the Com-

138. Id. art. 31. The draft covenant spoke of persons having "judicial or legal experience." The reference to "judicial experience" was deleted by the Third Committee by a vote of 86 in favor, 0 opposed and 3 abstentions, 21 U.N. GAOR, C.3 (1420th meeting) 249, para. 11, U.N. Doc. A/C.3/SR. 1420 (1966); Draft International Covenants on Human Rights, Report of the Third Committee, 21 U.N. GAOR, C.3 (Agenda Item 62) 56, para. 194 and 58, para. 207, U.N. Doc. A/6546 (1966) [hereinafter cited as Draft International Covenants Report]. The Commission on Human Rights draft also called for persons of "high moral standing" which was amended to read "high moral character." Draft International Covenants Report, id. at 56, para. 193 and at 58, para. 206. The Racial Discrimination Convention Article 8(1), provides that experts of "high moral standing and acknowledged impartiality" serve on the Committee on the Elimination of Discrimination (Article 8). The American Convention requires that the Inter-American Commission be composed of seven members of "high moral character and recognized competence in the field of human rights" (Article 34).

139. Civil and Political Covenant, supro note 101, art. 28.

140. Id. art. 32(1).

141. Id. art. 35. In contrast, under Article 8(6) of the Racial Discrimination Convention, State Parties are responsible for expenses of the members of the Committee. Expenses of the European Commission on Human Rights are to be borne by the Council of Europe (Article 58). Article 72 provides that the O.A.S. will provide "emoluments and travel expenses" for the members of the Inter-American Commission.

142. See id. arts. 29(1) and (2). This is considered an advance over the convention on the Elimination of All Forms of Racial Discrimination which in Article 8(2) provides that a State Party may nominate only one person from among its own nationals. The European Convention in Article 21(1) provides for election of the European Commission by the Committee of Ministers. Each State Party may put forward three candidates, two of whom shall be its own nationals. The American Convention on Human Rights goes even further than the European Convention in attempting to provide that an individual is not dependent for nomination and election upon his/her state of nationality (Article 36(2)). Each government may propose up to three candidates who may be nationals of any Member State of the Organization of American States. A slate of three must include at least a nominee who is a national of another Member State. 
mittee. ${ }^{143}$

Thus, some attempt was made to make the Human Rights Committee independent of governmental control. Capotori comments favourably on the composition of the Human Rights Committee.

A body composed of individuals independent from governments is . . . exclusively bound to general interests: its members will enjoy larger freedom of initiative and will be capable of assuming a critical position, if they think it necessary, with greater objectiveness. For this reason the solution adopted in the Covenant on Civil and Political Rights seems to be far better. . . . ${ }^{144}$

\section{A. Functions of the Committee}

The Human Rights Committee has five major functions:

(1) To study reports submitted by States Parties and to transmit the reports, and such general comments as it may consider appropriate, to the States Parties concerned. It may also transmit these comments to the Economic and Social Council. All States Parties to the Covenant are subject to these requirements. ${ }^{145}$

(2) The Committee is empowered to consider interstate communications and, communications from a State Party which considers that another State Party is not giving effect to the provisions of the Covenant. For this procedure to be utilized both States Parties involved must recognize the competence of the Committee to receive interstate communications. The Committee shall make available its good offices to the State Parties concerned with a view to a friendly solution to the matter.

(3) If a matter referred to the Committee in accordance with Article 41 is not resolved to the satisfaction of the States Parties concerned, the Committee may, with the prior consent of the States

143. Commission on Human Rights, Report of the Seventh Session, 13 U.N. ESCOR SuPP. (No. 9) 17, para. 78, U.N. Doc. E/1992 (1951). An attempt to reinstate the provision in 1953 was unsuccessful, Commission on Human Rights, Report of the Ninth Session, 16 U.N. ESCOR, SUPP. (No. 8) 20-21, paras. 181-184 and Annex III, at 69, paras. 175-176, U.N. Doc. E/2447 (1953). A provision for members ad hoc appears in Article 8 of the 1962 Protocol to the UNESCO Convention Against Discrimination in Education (1962).

144. Capotorti, supra note 116 , at 136 . There is a related area where the neutrality of the Committee is in question. The Civil and Political Covenant does not require that members of the Committee be nationals of a state which has accepted the optional interstate communication procedures contained in Article 41 or the Optional Protocol's right of individual petition. Such committee members may be nationals of states having objections to such procedures who will, on political and philosophical grounds, be reluctant to find any nation "at fault."

145. Civil and Political Covenant, supra note 101, art. 40. 
Parties, appoint an ad hoc conciliation commission. The good offices of the Commission shall be made available to the States Parties concerned with a view to an amicable solution of the matter.

(4) The Committee is competent to receive and consider communications from individuals who claim to be "victims" of a violation by a State Party to the Optional Covenant of any of the rights enumerated in the Covenant. The Committee shall forward its views to the State Party and to the individual concerned.

(5) The Committee, pursuant to Article 45, shall submit to the General Assembly through the Economic and Social Council, an annual report on its activities.

1. Reports. Article 40 provides for a mandatory reporting system under which States Parties to the Covenant "undertake to submit reports on the measures they have adopted" which "give effect" to the rights recognized in the Covenant and "on the progress made in the enjoyment of those rights." 146 The first report is to be submitted within one year after "entry into force" of the Covenant and thereafter whenever "the Human Rights Committee so requests." 147 Reports shall indicate the "factors and difficulties . . . affecting" the implementation of the Covenant. ${ }^{148}$

General guidelines for the content and form of States Parties' reports were formulated at the second session of the Human Rights Committee. ${ }^{149}$ These guidelines are designed to ensure that reports are presented in a uniform fashion to enable the Committee to obtain a comprehensive picture of the implementation of human rights in each state. The first part of the report should describe briefly "the general legal framework within which civil and politi-

146. Id. art. $40(1)$.

147. Id. art. $40(1)(\mathrm{a})(\mathrm{b})$.

148. Id. art. 40(2). The original Afro-Asian Amendments, supra note 131, at art. 39 , provided that the parties report on "the progress made in giving effect to the rights recognized herein." This was modified in the existing language providing for reports to comment on "progress made in the enjoyment of those rights." The original language might have been interpreted to mean that the governmental action giving effect to the rights might have been undertaken progressively. The final text restricts the "progressiveness" to the "enjoyment" of the right, e.g. to the results of the governmental action without implying that governmental action might be undertaken progressively. For debate see Miss Hart (New Zealand), 21 U.N. GAOR, C.3 (1426th meeting) 282, para. 32, U.N. Doc. A/C.3/SR.1426 (1966); Miss O'Leary (Ireland), 21 U.N. GAOR, C.3 (1427th meeting) 285, para. 2, U.N. Doc. A/C.3/ SR.1427 (1966); Mrs. Ramaholimihaso (Madagascar), 2 I U.N. GAOR, C.3 (1427th meeting) 289, paras. 29-30, U.N. Doc. A/C.3/SR.1427 (1966); Mr. Sanon (Upper Volta), id. at 289, para. 35; Mr. Mohammed (Nigeria), id. at 289, para. 36.

149. Id. 
cal rights are protected" in a country. The second part should describe "the legislative, administrative or other measures in force in regard to each right" and any "restrictions of limitations, even of a temporary nature imposed by law or practice or in any other manner, on the enjoyment of the right." 150

The report should also describe any other factors or difficulties effecting the enjoyment of the right by persons within the jurisdiction of the State, and provide any other information on the progress made in the enjoyment of the right. The report should be accompanied by copies of States Parties' principle legislative and other texts. In addition, the Committee would welcome additional information on any significant new developments in a country regarding the rights referred to in the Covenant. ${ }^{151}$

Reports are to be submitted to the Secretary-General of the United Nations who shall transmit them to the Human Rights Committee for consideration. ${ }^{152}$ The Secretary-General may, after consulting with the Committee, transmit copies of the reports to the appropriate United Nations agencies. ${ }^{153}$ The Human Rights Committee shall then study the reports submitted by the Parties and shall transmit the reports and such "general comments as it may consider appropriate" to the Parties concerned. The Committee may also transmit these comments to the Economic and Social Council along with copies of the reports it has received from States Parties to the Covenant. ${ }^{154}$ The States Parties concerned may also submit to the Committee "observations on any comments that may be made" by the Committee. ${ }^{\text {iss }}$

The reporting procedure appears to be a mechanism primarily

150. Id.

151. See Human Rights Committee Adopts Guidelines For States Reports, 14 U.N. Chronicle 41 (August-September 1977); Committee Considers States' Reports, Complaints From Individuals, 15 U.N. Chronicle 31 (March 1978).

152. Civil and Political Covenant, supra note 101, art. 49(2).

153. Id. art. 40(3).

154. Id art. 40(4).

155. Id art. 40(5). The International Covenant on Economic, Social and Cultural Rights, supra note 115, at art. 19, provides for reports to be submitted to the Economic and Social Council which may transmit them to the Commission on Human Rights for study and "general recommendations." The Economic and Social Council may submit, "from time to time," to the General Assembly reports with recommendations of a "general nature" and a summary of the information received from the States Parties to the present Covenant (Article 21). Thus, the Economic and Social Council may go beyond "comments" and make "general recommendations." Under the Covenant on Racial Discrimination, the Committee on the Elimination of Racial Discrimination may, after having considered reports by States Parties make "suggestions and general recommendations based on the examination of the reports and information received from the States Parties" (Article 9(2)). 
for gathering information on Human Rights. The effectiveness of the reporting system depends upon whether States Parties submit timely and accurate reports. However, states may be reluctant to admit to or to recognize any inadequacies in their protection of human rights.

Not only have governments been unwilling and unable to escape the bias of their own perspectives, but the information they have been furnishing can hardly be said to provide an expanding vision of reality. In the first place, there are fixed national habits of thought that assign different values to the same fact or set of facts. Secondly, the separate facts do not add up to make a whole; if for no other reason than that they are rarely representative samples of the total situation they attempt to describe. The irrelevancies contained in the reports are only exceeded by their omissions. . . . Ten years of periodic reports have not given us a settled vision of the world scene of human rights. ${ }^{156}$

The Human Rights Committee has limited resources to devote to examination of the reports and with which to evaluate the adequacy of state compliance. Capotorti argues that examination of reports is "deeper and more accurate when . . . discussed by one or more technical organs before they are submitted to the political organ entrusted with the power of addressing recommendations. . ."157 Capotorti further argues that the availability of sources of information other than state reports is a vital component of "efficient control."

Since the Human Rights Committee is not empowered to go outside the States' report in evaluating the effectiveness of the States' human rights protection, the Committee is limited to mak-

156. Moskowitz, The Politics of Human Rights (1968), cited in R.S. CLARK, A UNITED Nations High Commissioner for Human Rights (1972). According to 14 U.N. Chronicle, supra note 151, at 42, at the end of August 1977 only 17 of the 37 states "due to submit their reports" had done so. At the end of March 1978, 18 of the states still had not submitted reports. 15 U.N. ChroniCle, supra note 151, at 31.

157. Capotorti, supra note 116, at 136-37. Capotorti looks approvingly at the International Labor Organization and European Social Charter:

[I]n the International Labor Organization . . . reports are examined by an expert committee and are then summarised and transmitted to the relevant committee of the General Conference with the observations of the experts. The latter Committee discusses the conclusions of the first examination and finally submits its own detailed report to the Conference in plenary meeting. It is for the Conference to adopt this report and to formulate appropriate recommendations. The European Social Charter establishes an even more complex procedure: reports are examined by an expert Committee; the Committee's conclusions are transmitted both to the Assembly of the Council of Europe, for its advice, and to a Sub-Committee of the Social Committee of the Council of Europe. The Sub-Committee reports to the Committee of Ministers and the latter may address its recommendations to the States after further consultation with the Assembly. 
ing general comments to States Parties. These comments along with responses by States Parties may then be transmitted to the Economic and Social Council. No provision is made for the Committee to make specific recommendations to governments or to initiate further action. The action which may be taken by the Economic and Social Council is not set forth in the Covenant, but presumably the Council may take any action it deems appropriate within its powers under the Charter. Capotorti comments that the Committee's limited ability to act pursuant to States Parties reports is a reflection of the general nature of the reports.

[A] specific recommendation presumes an accurate verification of the circumstances. . . . Thus, wherever examination of reports is superficial-as it unfortunately is in the Covenant system-the only possible outcome consists in general recommendations: and these have the function of means for political pressure, rather than of true instruments for supervising the observance of the agreements. ${ }^{158}$

158. Id. at 138. It should be noted that the reporting system complements an existing procedure of the Commission on Human Rights instituted in 1956. ECOSOC REs. 624B (XXXII) of August 1, 1956, E.S.C.O.R. 22nd Sess., Supp. No. 1, at 12, U.N. Doc. E/2929 (1956): presently governed by ECOSOC Res. 1074 (XXXIX) of July 28, 1965, E.S.C.O.R. 39th Sess., Supp. No. 1, at 24-25 U.N. Doc. E/4117 (1965). Under the original 1956 Procedures Member States and specialized agencies were asked to submit to the Secretary-General a report every three years describing the developments and the progress achieved during the preceding three years in the field of human rights, and measures taken to safeguard human liberty in the States' metropolitan area and Non-Self-Governing and Trust Territories. It invited specialized agencies to transmit every three years a report in respect of rights coming within their purview. The Secretary-General was requested to prepare and forward to Governments suggestions which might serve as a guide for preparation of the reports by governments on a topical basis, and to prepare a brief summary of the reports for the Commission on Human Rights, the first reports were to cover the years 1954-1956. State Members and specialized agencies were invited to include a separate section on rights designated by the Human Rights Committee. At the Thirty-ninth Session of the Economic and Social Council in 1963 the system of reporting was revised and information was to be submitted within a continuing three-year cycle; (a) in the first year on civil and political rights; (b) in the second year on economic, social and cultural rights; and (c) in the third year on freedom of information.

The Economic and Social Council on July 24, 1962 invited non-governmental organizations in consultative status to submit comments and observations of an objective character on the situation in the field of human rights to assist the commission in consideration of the summaries of periodic reports.

Sir Samuel Hoare, The U.N. Commission on Human Rights, in E. Luard ed., supra note 5 , at 59,86 , remarks that in addition to the fact that the reports have not been submitted by all U.N. Member States,

the reports are extremely uneven in presentation, content, and informativeness. They are naturally, despite exhortations to Member States in Council resolutions, to give information about difficulties encountered, more concerned with recounting achievements than with recording inadequacy or failure. Nor have the conclusions that it has been possible to draw from them so far been very enlightening. Some, 


\section{B. Optional Interstate Complaints}

An optional interstate complaint and conciliation procedure is provided for under Articles 41 and 42. The optional interstate procedure is only applicable to States Parties to the Civil and Political Covenant which declare that they "recognize the competence" of the Human Rights Committee to receive and consider communications from another State Party. All communications shall be in writing, and no communication shall be received by the Committee from or concerning a State Party which has not made such a declaration. ${ }^{159}$

Under the optional interstate procedure, if a State Party to the Covenant considers that another State Party "is not giving effect" to the provisions of the Covenant, it may bring the matter to the attention of the State Party so charged by a written communication. ${ }^{160}$ The State Party allegedly "not giving effect to the provisions of the present Covenant" shall respond to the complaining State Party with an "explanation or any other statement in writing clarifying the matter" which "should," to the "extent possible and pertinent," include reference to "domestic procedures and remedies taken, pending or available." 161 If the matter is not "adjusted to the satisfaction of both States Parties" within six months of receipt of the initial communication, "either State shall have the right to refer the matter to the Human Rights Committee." 162

The Human Rights Committee shall "deal" with the matter referred to it in closed session, ${ }^{163}$ only after having ascertained that all domestic remedies "have been invoked and exhausted." 164 The States Parties concerned shall have the "right to be represented when the matter is being considered" and shall have the "right to make oral and written submissions." 165 The Committee is to consider the matter with a view toward a "friendly solution" on the

but not many, non-governmental organizations have so far contributed comments and observations.

159. Civil and Political Covenant, supra note 101, art. 41(1). The Convention on Racial Discrimination provides for a mandatory interstate complaint and conciliation system under Article 11.

160. "Not giving effect to the provisions of the present Covenant," presumably includes violation of both substantive and procedural provisions (e.g. failure to submit a report).

161. Civil and Political Covenant, supra note 101, art. 41(a).

162. Id. art. 41(b).

163. Id. art. 41(d).

164. Id. art. $41(\mathrm{c})$.

165. Id. art. $41(\mathrm{~g})$. 
basis of "respect for human rights and fundamental freedoms." 166 The Committee has twelve months after receipt of notice to submit a report. ${ }^{167}$ In the event a solution is reached, the Committee shall confine its report to a synopsis of the facts and the solution. If no solution is reached, the Committee shall confine its report to a "brief statement of the facts." The written submissions and the record of oral submissions made by the States Parties shall be attached to the Committee's report. ${ }^{168}$

1. Weaknesses. The State Party initiating the complaint does not have to demonstrate any "harm" in order to bring the matter to the attention of the "receiving" state or the Human Rights Commit-

166. Id. art. $41(\mathrm{e})$.

167. Id, art. $41(\mathrm{~h})$.

168. Id art. 4(h)(ii). Under the American Convention of Human Rights, if a friendly settlement has been reached, the Commission shall draw up a report which shall be transmitted to the petitioner, to the States Parties to the Convention and also to the Secretary-General of the Organization of American States for publication. The report shall "contain a brief statement of the facts and of the solution reached." If any Party involved in the matter so requests, the "fullest possible information shall be provided to it." If a settlement is not reached, the Commission shall draw up a report "setting forth the facts and stating its conclusions." If within three months from the date of transmittal of the report to the States Parties concerned, the matter has not been either settled or submitted by the Commission or by the State concerned to the Inter-American Court of Human Rights, the Commission may, by majority vote, set forth "its opinion and conclusions" concerning "the questions submitted for its consideration." Where "appropriate," the Commission shall make "pertinent recommendations" and shall prescribe a period within which the State is to take the measures that "are incumbent upon it to remedy the situation examined." When the prescribed period has expired, the Commission shall decide by majority vote whether the State has taken adequate measures and whether to publish its report.

See arts. 48, 49, 50, 51. These provisions which provide for a statement of "conclusions" and "recommendations" are stronger than those in the Civil and Political Covenant. Under the European Convention on Human Rights, if a "friendly settlement is reached between the parties" a report shall be sent to the parties concerned, to the Committee of Ministers and to the Secretary-General of the Council of Europe for publication. The Report shall be confined to a "brief statement of the facts and of the solution reached." If a solution is not reached the Commission shall draw up a Report on the facts and state its opinions as to "whether the facts disclose a breach by the State concerned of its obligations under the Convention." The opinions of all members of the Commission on this point may be stated in the Report and shall be transmitted to the Committee of Ministers who, if they do not refer the matter to the European Court of Human Rights, ". . . shall decide by a majority of twothirds whether 'there has been a violation of the Convention.' "If a violation has taken place, the Committee may prescribe a period during which the Contracting Party must take the measures required by the Commission. If the Contracting Party does not comply, the Committee of Ministers shall decide "what effect shall be given to its original decision and publish the report" (Articles 24, 25, 31). Under both the American and European Conventions complaints may originate from any person, group of persons or Contracting State Party. See American Convention arts. 44, 45; European Convention arts. 24, 25. However, under the European Convention complaining persons and non-governmental organizations must claim to be victims of a violation of one of the Contracting Parties. 
tee. The State Party's action is an actio popularis; a remedy available to and on behalf of every member of the Community of Nations. ${ }^{169}$ The States Parties concerned also have the discretion to determine, without reference to the interests of the Community of Nations, whether the "matter" has been "adjusted to the satisfaction of both States Parties." Both States shall have the discretionary right to refer the matter to the Committee, and the discretion to determine whether the "good offices" of the Human Rights Committee have resulted in a solution which respects human rights and fundamental freedoms. In the event a solution is not reached, States may consent to the matter being considered by an ad hoc Conciliation Commission. ${ }^{170}$

The Covenant is further weakened in that the implementation procedures are designed to reconcile the parties rather than to reach a decision on the merits. As a result, the Committee's procedures are insulated from public view and pressure. The Committee holds closed meetings when examining communications, and Article 4l(7)(ii) provides that communication of the final report is to be made only to the States Parties concerned and, presumably, to the Economic and Social Council. ${ }^{171}$ The Committee's limited role is further illustrated by the fact that if a "friendly solution" which respects human rights and fundamental freedoms is not reached, the Committee must confine its report to a brief statement of the facts and any written submissions by the States Parties concerned. No provision is made for dissenting statements of the facts. ${ }^{172}$ If a

169. Judge Winiaski, Southwest Africa Cases [dissent], Southwest Africa Cases, [1962] I.C.J. 449, 452 [preliminary objections].

170. See art. 42, discussed infra. An additional question concerns Article 41(c) which requires exhaustion of domestic remedies, presumably by the individual whose rights allegedly have been violated. It might be argued that an individual's exhaustion of domestic remedies should not be a condition precedent to vindication of the interests of the Community of Nations. Starr, supra note 91 , at $880 \mathrm{n} .82$.

171. The American Convention on Human Rights provides in Article 49, that if a "friendly settlement" has been reached, the Secretary-General of the OAS shall publish the report. If a settlement has not been reached and the case has not been referred to the InterAmerican Court, the Commission has the discretion to publish its "opinion and conclusions" in the event that the offending state has not taken the measures incumbent upon it to remedy the situation (Articles 49, 51). The European Convention on Human Rights in Article 30 provides for publication of the report of the Subcommission of the European Commission on Human Rights which considered the matter in the event a "friendly solution" is not reached. If a "solution has not been reached," and the matter has not been referred to the European Court of Human Rights, the Commission may publish its report in the event it considers that a violation has occurred and the offending state has not taken "satisfactory measures" within the "prescribed period" to remedy the situation (Article 32). See supra note 168.

172. Civil and Political Covenant, supra note 101, art. 41(h)(ii). The Inter-American 
solution is not reached, the Committee's only recourse is to attempt to gain the consent of the parties, encouraging them to submit to a formal conciliation procedure. ${ }^{173}$

The effectiveness of the interstate procedure may also be limited by the time involved in the complaint process. There is no statute of limitations within which the "complaining state" must bring the matter to the attention of the "receiving state." After receipt of the initial communication, the States Parties have six months within which to reach an "adjustment of the matter." If the matter is taken to the Human Rights Committee, the Committee is given twelve months in which to issue a report. If a "solution" is not reached the matter may be referred to a Conciliation Commission which is given an additional twelve months to issue a report. ${ }^{174}$ The end result is that human rights violations may not be swiftly acted upon.

Finally, the interstate complaint procedure is restricted to those States Parties to the Covenant on Civil and Political Rights

Convention, art. 50 and the European Convention, art. 31 both provide for dissenting opinions in the event an initial settlement is not reached.

173. The original Afro-Asian Amendment Draft, supra note 131, spoke of the Committee receiving and considering "complaints" by States. In a revised version, "complaint" was replaced by "communication." The Third Committee apparently tried to eliminate any terminology creating the impression that the Committee would be concerned with "disputes" and "cases." Draft International Covenants Report, supra note 138, at 92-93, para. 402. In 1953 the Committee on Human Rights adopted a United Kingdom Amendment based on the provision on the European Commission on Human Rights instructing the Committee, to "draw up a report on the facts and state its opinion as to whether the facts found disclosed a breach of the State concerned of its obligations. . ." The clause ultimately was deleted. The present phraseology was adopted 58 in favor, 0 opposed and 24 abstentions, id. at 298, para. 54. The rejection of the language proposed by the United Kingdom seems to have been based on the belief that a clear distinction should be maintained between the "good offices" provided by the Committee and judicial functions exercised by the International Court of Justice. See Mrs. Dick (USA), 18 U.N. GAOR, C.3 (1273rd mtg.) 329, para. 20, U.N. Doc. A/C.31/SR.1273 (1963). At the same time, it was recognized that the threat of judicial scrutiny of human rights disputes would be a strong impetus to settlement, between the State Parties; Miss O'Leary (Ireland), 21 U.N. GAOR, C.3 (1429th mtg.) 300, para. 8, U.N. Doc. A/C.3/SR.1429 (1966). However, the Committee's "brief statement of facts" might reflect the Committee's view of the merits of the dispute since, "a brief statement of the facts" covers facts as ascertained by the Committee. See Mr. Saksena (India), 21 U.N. GAOR, C.3 (1428th mtg.) 294, para. 11, U.N. Doc. A/C.3/SR.1428 (1966).

174. See art. 42 infra. The Netherlands proposed an amendment which would have limited the Committee to considering communications brought within six months from the date of decision by domestic authorities. See Civil and Political Covenant, supra note 101, at 107, para. 446. Subsequently, the Netherlands reconsidered its proposal and concluded that this might prevent the Committee from examining bona fide communications. Mrs. ZeydnerRempt (Netherlands), 21 U.N. GAOR C.3 (1428th mtg.) 293, para. 9, U.N. Doc. A/C.3/ SR.1428 (1968). 
which have recognized the competence of the Committee to receive and consider communications. ${ }^{175}$ However, even if most States Parties did recognize the competence of the Human Rights Committee to receive interstate complaints, it is questionable whether human rights would then be effectively protected. States are not apt to risk straining diplomatic relations by lodging a complaint against another State Party, particularly when its own nationals may not be involved. Such complaints may also open the complaining state to criticism concerning treatment of its own citizens, as well as strain diplomatic relations with third-party states. Conversely, given the ease with which interstate complaints can be lodged, states may begin to utilize the interstate complaint procedure as a vehicle for embarrassing "unfriendly nations" and attacking competing social systems. This might reduce human rights to a political issue, with its value limited to being just another tool of international diplomacy. ${ }^{176}$

Schwelb points out that interstate complaint procedures in other international instruments have rarely been utilized, and then almost only for political purposes. ${ }^{177}$ For instance, since the establishment of the International Labor Organization (I.L.O.) in 1919, only two complaints have been filed. ${ }^{178}$ Schwelb also cites three groups of interstate complaints referred to the European Commission as evidence of the political nature of the interstate complaint process: the complaint arising from the tensions associated with

175. As of January 1, 1978, Amnesty International reports that Article 41 had been accepted by Denmark, Finland, the Federal Republic of Germany, Norway, Sweden, and the United Republic of Norway. Amnesty International Report 1978.

176. The American Convention on Human Rights (Article 44) and the European Convention on Human Rights (Article 25) partially avoid the problems associated with the politics of international diplomacy by providing for the lodging of complaints by individuals and non-governmental organizations. The argument that the process is too flexible and may encourage frivolous complaints and inflame international tensions is put forth by Mr. Ozgur (Cyprus), 21 U.N. GAOR, C.3 (1428th mtg.) 295, para. 28, U.N. Doc. A/C.3/SR.1428 (1966).

177. Schwelb, supra note 120 , at 161 .

178. The two cases were a complaint by Ghana against Portugal and a complaint by Portugal against Liberia. Schwelb remarks that, "It is not difficult to discern that both complaints were motivated by foreign policy considerations of the states concerned." Id. See Report of the Commission appointed under Article 26 of the I.L.O. Constitution to examine the complaint filed by the Government of Ghana concerning the observance by the Government of Portugal of the Abolition of Forced Labor Convention, (1957) (No.105), I.L.O. OFfiCial Bulletin, Supp. 11, April 1962 (Vol.45, No.2); and Report of the Commission appointed under Article 26 of the I.L.O. to examine the complaint filed by the Government of Portugal concerning the observance by the Government of Liberia of the Forced Labor Convention, 1930 (No.29), I.L.O. Official Bulletin, Supp. 11. (April 1963) (Vol. 46, No. 2). 
United Kingom sovereignty over Cyprus; ${ }^{179}$ the complaint stemming from "the status of the German-speaking element in the province of Bolzen; ${ }^{180}$ and the complaint concerning British treatment ${ }^{181}$ of Catholics in Northern Ireland.

Schwelb concedes that there are isolated examples, such as the Greek torture case, where interstate complaints appear to have been based upon legal and moral, rather than upon political grounds. ${ }^{182}$ It also has been argued that a States' failure to use interstate procedures demonstrates "the responsible attitude taken towards the procedure and its value." The procedure (interstate complaints under the Covention on the Elimination of All Forms of Racial Discrimination) was a deterrent, encouraging Governments to quickly remedy any abuse of human rights within their territory. ${ }^{183}$ This deterrence argument is difficult to refute, yet it lacks persuasiveness given the alleged wide-spread human rights violations in the world. ${ }^{184}$

\section{Conciliation Commission}

If a matter referred to the Human Rights Committee in accordance with Article 41 is not resolved to the "satisfaction" of the States Parties concerned, the Committee may, "with the prior consent" of the States Parties, appoint an "ad hoc Conciliation Commission."185 The Commission shall consist of five persons

179. Greece v. United Kingdom [1956] and Greece v. United Kingdom [1957], [1958-59] Y.B. Eur. Cónv. on Human Rights 174-99 (Eur. Comm. on Human Rights), Documents and decisions, 1955-1956-1957, at 128-31.

180. Austria v. Italy, [1961] Y.B. EuR. Conv. on Human Rights No. 116 (Eur. Comm. of Human Rights); id. [1962] at 54; id. [1963] at 740 (Comm. of Ministers).

181. Applications by Ireland of 1971 and 1972. See Communications by the Council of Europe to the Commission on Human Rights of the United Nations, Council of Europe. Doc. H(75) 3 (1975).

182. Denmark, The Netherlands, Norway and Sweden v. Greece, [1968] Y.B. EuR. Conv. On Human Righrs. 690 and 730 (Eur. Comm. of Human Rights), id. [1970] at 108 and 122.

183. Lady Gaitskell (United Kingdom), 21 U.N. GAOR, C.3 (1415th mtg.) 223, para. 29, U.N. Doc. A/C.3/SR.1415 (1966).

184. See Amnesty International Report 1977 and 1978, supra note 115 detailing abuse of human rights in over 110 countries in both years.

185. The Human Rights Committee has the authority to take the initiative in soliciting the "prior consent of the parties," this resulted from a United States amendment, approved by a narrow majority of the Third Committee, replacing a provision of the Afro-Asian draft under which convening of an ad hoc Conciliation Commission only would have been possible "at request" of both parties. The United States amendment was adopted by a vote of $\mathbf{4 2}$ in favor, 32 opposed and 19 abstentions. Draft International Covenants Report, supra note 138 , at 107 , para. 460 . 
"acceptable to the States Parties" concerned. If the States Parties fail to reach agreement within three months on all or part of the composition of the Commission, the members shall be elected by secret ballot requiring a two-thirds majority vote of the Human Rights Committee. ${ }^{186}$ The members of the Commission shall serve in their "personal capacity," and they shall not be nationals of the States Parties concerned, nor of a State not a party to the Covenant, nor of a State which has not made a declaration under the Article 41 inter-state complaint procedure. ${ }^{187}$

The Commission's mandate is to make "its good offices . . . available" to the States Parties concerned "with a view to an amicable solution of the matter on the basis of respect for the present Covenant." 188 To fulfill this mandate, information received and collated by the Committee shall be made available to the Commission, and the Commission may call upon the States Parties concerned to supply any other relevant information. ${ }^{189}$ When the Commission "has fully considered that matter," but "in any event not later than twelve months after having been seized of the matter," it shall submit a report to the Chairman of the Human Rights Committee. ${ }^{190}$ If an "amicable solution" of the matter on the basis of "respect for human rights" is reached, the Commission shall confine its report "to a brief statement of the facts and of the solution reached." 191 If such an "amicable solution" is not reached, the Commission's report, "shall embody its findings on all questions of fact relevant to the issues between the States Parties concerned, and its view on the possibilities of an amicable solution of the matter." 192 This report shall also contain the written and oral submissions of the States Parties concerned. ${ }^{193}$ The States Parties shall, within three months of receipt of the report, notify the Chairman of the Committee whether or not "they accept the Commission's report." 194

186. Civil and Political Covenant, supro note 101, art. 42(b).

187. Id. art. 42(2).

188. Id. art. 42(1)(a).

189. Id. art. $42(6)$.

190. Id. art. 42(7).

191. Id. art. 42(a)(b).

192. Schwelb, supra note 120 , at $174-77$ questions whether "views" was improperly substituted for "recommendations." The original French sub-amendment read "ses constations," which Schwelb argues at the time the sub-amendment was offered was said to mean, "its views," implying to establish, verify, ascertain, note.

193. Civil and Political Covenant, supra note 101, Part IV, art. 40(2).

194. Id. art. 41(1)(a). 
The optional conciliation procedure might be more effective if it were compulsory. ${ }^{195}$ This would encourage States Parties to work towards dispute settlement during the initial stages so as to avoid the conciliation requirement. Such settlements might also be encouraged if the Conciliation Commission's powers were strengthened to enable it to make "such recommendations as the Commission may think proper for the amicable solution of the dispute." Further, though the Conciliation Commission's report is to be submitted to the Human Rights Committee, no explicit provision is made in Article 42 for publication of the report. In addition to a compulsory and strengthened Conciliation procedure, a wide distribution of the Committee's report may increase the effectiveness of the Article 42 procedure. ${ }^{196}$

Based on his analysis of various international human rights procedures, Capotorti argues that if human rights instruments are to be effective, they must provide both an organ empowered to make a determination on the merits of a situation, and judicial enforcement of such determinations.

The higher effectiveness of systems including a clause of compulsory jurisdiction of an international court needs not to be [sic] underlined: only such clauses, in fact, ensure a final solution of the dispute, even though one of the States Parties is interested in obstructing any legal solution. Moreover, the fact that the State Party which failed to fulfill its obligations can be bound to redress the injury, is a concrete measure to guarantee the implementation of the agreement. . . . In the field of human rights, conciliation has to face the limit of certain principles which cannot be a subject for compromise. . . . ${ }^{197}$

195. The International Convention on the Elimination of All Forms of Racial Discrimination does not provide for an intermediate Human Rights Committee "type" process. Instead, complaints are to be initially directed to the Committee on the Elimination of Racial Discrimination which shall "obtain and collate all the information it deems necessary." It is then transmitted to a five-person ad hoc Conciliation Committee which makes its "good offices" available with a view "to an amicable solution of the matter" (Article 12 (I)(a)). After having "fully considered the matter," the Commission shall prepare a report "embodying its findings on all questions of fact relevant to the issue between the parties and containing such recommendations as it may think proper for the amicable solution of the dispute" (Article $13(1)$ ). The report shall be communicated to the States Parties concerned for comment and within three months the report and any declarations by the States Parties concerned are to be communicated to the other States Parties to the Convention (Article 13 (2)(3)).

196. One anomaly in the provisions for the Conciliation Committee is Article 12(6) providing that the States Parties share equally the expenses of the Commission. This would seem to discourage utilization of the procedure.

197. Capotorti, supra note 116 , at 142. 


\section{Optional Individual Right To Petition}

The draft Covenant submitted by the Commission to the General Assembly in 1954 did not provide for the right of individual petition to the Human Rights Committee. ${ }^{198}$ At the Twentyfirst session of the General Assembly in 1966, the Netherlands delegation proposed that an article be inserted into the Covenant empowering the Human Rights Committee to receive petitions from individuals or groups of individuals claiming to be victims of a violation by a State Party, provided that the State Party has declared the Committee competent to receive such petitions. ${ }^{199}$ A group of Afro-Asian states subsequently offered a similar provision calling for the right of individual petition ${ }^{200}$ which was later merged into a draft provision cosponsored by a cross-section of twelve Member States. ${ }^{201}$ The Third Committee decided that the draft should be included in a separate protocol to be annexed to the Civil and Political Covenant. ${ }^{202}$ Pursuant to this vote, Nigeria submitted a proposal for a "draft optional protocol" 203 to be annexed to the International Covenant on Civil and Political Rights. The Third Committee approved the "Optional Protocol"204 which was adopted by the General Assembly. ${ }^{205}$ The provision for individual petition was included in a separate protocol so as not to imply any recognition of the locus standi of the individual by nation-states signing, ratifying or acceding to the Covenant. ${ }^{206}$

198. Supra note 116.

199. 21 U.N. GAOR (Agenda Item 95) 1, U.N. Doc. A/C.3/L.1335 (1966) Report of the Third Committee, Note 14, at 119 , para. 474, for the introductory statement by the representative of the Netherlands (Mr. Mommersteeg), see 21 U.N. GAOR, C.3 (1414th mtg.) 217-18, paras. 24-25.

200. 21 U.N. GAOR (Agenda Item 62) 1-2, U.N. Doc. A/C.3/L.1402 (1966) (Cosponsored by Iran, Lebanon, Nigeria, Pakistan).

201. (Cosponsored by Canada, Columbia, Costa Rica, Ghana, Jamaica, Iran, Lebanon, The Netherlands, Nigeria, Pakistan, Phillippines and Uruguay) 21 U.N. GAOR (Agenda Item 62) I, U.N. Doc. A/C.3/L.1402/Rev.2 (1966). The text was considered at the 1438th to 1441 st meeting of the Third Committee.

202. The vote was 41 for, 39 against with 16 abstentions. 21 U.N. GAOR, C.3 (1440th mtg.) 379, para. 52, U.N. Doc A/C.3/AR.1440 (1966). See also Draft International Covenants Report, supra note 138, at 123, para. 485.

203. 21 U.N. GAOR (Agenda Item 62) 1-4, U.N. Doc. A/C.3/L.1411 (Nov. 30, 1966). A revised version of this proposal was cosponsored by Canada, Chile, Costa Rica, Ghana, Jamaica, Lebanon, The Netherlands and the Philippines. U.N. Doc. A/C.3/L.1411/ Rev. 1 and Rev. 2 (Dec. 1, 1966).

204. The vote was 59 for, 2 against and 32 abstentions. 21 U.N. GAOR, C.3. (145 Ist mtg.) 450, para. 16, U.N. Doc. A/C.3/SR.1451 (1966).

205. 21 U.N. GAOR (1496th plen. mtg.) 6, para. 60, U.N. Doc. A/Pv. 1496 (1966).

206. The Third Committee had originally decided to include the draft article on individual petition in a "separate" protocol "annexed" to the Covenant. Eventually, the view pre- 
Schwelb notes that "[t]he drafting of a separate protocol made it possible to achieve the unanimous adoption of the Covenant and the adoption of the Protocol by a very great majority, against only two votes [Niger and Togo], albeit with a large number of abstentions."207 As of January 1978 there were fourty-four parties to the International Covenant on Civil and Political Rights, only sixteen of whom were parties to the Optional Protocol. ${ }^{208}$ On the other hand, as of 1 May 1978 there were one hundred States Parties to the International Covention on the Elimination of All Forms of Racial Discrimination, only five of whom had accepted the Covention's optional procedure for individual petition included within the Racial Discrimination Covenant. ${ }^{209}$ Based on these statistics, it might be argued that creating a separate Protocol has placed pressure on states to sign both the International Covenant on Civil and Political Rights and the Optional Protocol. If the optional right of petition

vailed "that it was impossible to have a Protocol both 'separate' and 'annexed." Mrs. Saksena (India), 21 U.N. GAOR, C.3 (1451st mtg.) 453-54, para. 62, U.N. Doc. A/C.3/ SR.1451 (1966). Mr. Schreiber, the Director of the Division of Human Rights, made it clear that the Covenant and the Protocol were separate instruments, although they were substantially related, since only parties to the Covenant could become parties to the Protocol. It should be noted that International Convention on the Elimination of All Forms of Racial Discrimination, 1966, recognizes the right of individual petition within the main text (Article 14). The American Convention on Human Rights provides for an optional interstate complaint procedure (Article 45) and a mandatory provision for petition by individuals and nongovernmental organizations (Article 44 ). In reference to the procedures for individual petition under the Covenant on Racial Discrimination and the Covenant on Civil and Political Rights, Capotorti observes,

[t]he most interesting difference is that the Committee for the Elimination of Racial Discrimination has more restricted powers to declare an individual communication admissible; in particular, the Convention does not make reference to any abuse of the right of petition. At the end of the procedure, the Committee may transmit its 'suggestions and recommendations' to the State concerned and to the individual: these terms are more precise than the word 'views' used in the Protocol and imply a greater degree of authority on the part of the Committee. It is also to be noted that each Party to the Convention may entrust a new or existing domestic body with the task of a preliminary consideration of individual petitions.

Capotorti, supra note 116, at 143, 144.

207. Schwelb, supra note 120 , at 179. Schwelb goes on to note that apart from such practical considerations that there is no legal difference between inclusion of the optional right of individual petition within the body of a treaty and inclusion of the right of petition in a separate Protocol. He observes that in addition, in both cases ratification of the main instrument is required as a condition precedent to recognition of the right of individual petition.

208. Amnesty International, supra note 115, at 50. The interstate complaint procedure interestingly has only been adopted by six states. The optional right of individual petition in the Racial Discrimination Convention has only been accepted by 5 states.

209. United Nations, Towards A World Without Racism 6 (1978). Admittedly there was an international consensus concerning the desirability of the Convention on the Elimination of All Forms of Racial Discrimination. 
had been included within the Covenant, the pressure to accept the right of individual petition might not exist. ${ }^{210}$

The substantive provisions of the Optional Protocol are binding on all States Parties to the Covenant that recognize the competence of the Human Rights Committee to receive and consider communications from individuals. ${ }^{211}$ The Committee shall not consider any communication from an individual claiming to be a "victim" unless it has ascertained that: the individual has exhausted all available domestic remedies; application of such remedies is unreasonably prolonged; and it has determined that the same matter is not being examined under another procedure of "international investigation or settlement." 212 In addition, the Committee shall not consider any anonymous communication, or any communication which is considered to be an abuse of the right of submission, ${ }^{213}$ or which is "incompatible" with the provisions of the Covenant. ${ }^{214}$

If none of the obstacles set forth in Articles 3 and 5 prohibit Committee action, the communication will be brought to the attention of the State Party "alleged to be violating the Covenant." 15 Within six months after receipt of the communication, the "receiving state" shall submit to the Committee written "explanations or statements clarifying the matter and the remedy, if any, that may have been taken by that State." 216 The Committee shall consider

210. Additional evidence substantiating this point is the fact that only six states have accepted the interstate complaint procedure which is contained "within" the Covenant on Civil and Political Rights.

211. Civil and Political Covenant, supra note 101, art. 1. Initially the term "petition" is used, supra note 200. "Petition" was changed later to "communication," supra note 201, at 1. The delegate from France urged this modification, since "petition" was only available under the Trusteeship System. See statement by Mr. Paolini (France), 21 U.N. GAOR, C.3 (1418th mtg.) 242, para. 8, U.N. Doc. A/C.3/SR.1418 (1966). See United Nations Charter Article 87(b). However, this modification in language was interpreted as implying no substantive change, Mr. Gros Espiell (Urguay), 21 U.N. GAOR, C.3 (1438th mtg.) 364, para. 44, U.N. Doc. A/C.3/SR. 1438 (1966). The American Convention on Human Rights refers to "petitions" or "communications" (Article 48). The European Convention on Human Rights provides for submission of "petitions" (Article 27) and the International Convention of the Elimination of All Forms of Racial Discrimination in Article 14 refers to "communications" while Article $14(7)(a)(b)$ describes the initiating party as the "petitioner."

212. Civil and Political Covenant, supra note 101, art. 5(2)(a)(b).

213. Technically the Protocol distinguishes between grounds which make petition "inadmissible" and grounds on which the Committee "shall not consider a communication." The major distinction appears to be that "inadmissible" communications are not brought to the attention of the State Party involved.

214. Civil and Political Covenant, supra note 101, art. 3.

215. Id. art. 4(1).

216. Id. art. 4(2). 
communications received "in the light of all written information made available to it by the individual and by the State Party concerned."217 The Committee shall hold closed meetings when examining communications under the present Protocol and "shall forward its views" to the State Party and individual concerned. ${ }^{218}$

1. Problems With Initiating Individual Claims. Although the Optional Protocol should be applauded as a long needed progressive step in human rights, there are a number of procedural short comings which will probably limit the Covenant's effectiveness. The first obvious difficulty with the Optional Protocol is that an individual's right of petition is dependent upon whether the State which allegedly violated the individual's human rights is a party to the Protocol. The States Parties which are the greatest violators of human rights are probably the least likely to grant the right of petition to individuals. ${ }^{219}$ In addition, only individuals subject to States Parties jurisdiction have standing to bring a communication. Even assuming a "victim" is aware of the provisions of the Optional Protocol, "victims" imprisoned or tortured (or those who have been fatally injured) are not apt to be in a position to submit petitions. $^{220}$ "Victim" is also an ambiguous term which arguably encompasses individuals in prison, individual readers of a newspaper closed by government order, a third party closely associated with a prisoner, or an individual living in a state whose government

217. Id. art. $5(1)$.

218. Id. art. 5(3)(4). "Views" was preferred by the U.N. General Assembly to the seemingly stronger term "suggestions" contained in the initial draft. Tardu, The Protocol to the United Nations Covenant on Civil and Political Rights and the Inter-American System: A Study of Co-Existing Petition Procedures, 70 AM. J. INT'L L. 778, 780-81 (1976), citing U.N. Doc. A/C.3/L.1402. Rev. 2 and U.N. Doc. A/C.3/L.1411/Rev.2(1) (1966). Under the Optional Protocol the Committee offers its "views" on the substance of the matter as opposed to the Article 42 interstate communication provisions under which the ad hoc Conciliation Commission reports its "Findings" on the relevant facts and its "views on the possibilities of an amicable solution of the matter." Tardu argues that "views" in the Optional Protocol encompasses "judgments as to the conformity of conduct of the state with the covenant." $I d$. at 781.

219. Bilder, Rethinking International Human Rights: Some Basic Questions, 1969 WIS. L. Rev. 171, 205. See note 248 infra. It should be noted that Article 10 extends the Protocol to "all parts of federal states without any limitiations or exceptions." This presents problems for States Parties which are federally constituted states with limited delegations of power to the central government.

220. A related requirement is that the harm suffered by the "victim" must have occurred after the Optional Protocol has entered into force within the State Party against whom the petition is lodged. See 14 U.N. Chronicle, supra note 151, at 42. Another problem is determining how far the concept of "state action" should extend. 
has been overthrown. It is also important to provide some protection to "potential victims."

The harshness of the requirement that complainants be "victims" of a human rights violation is tempered by a 1977 ruling of the Human Rights Committee permitting communications to be submitted by the "victim" or his or her "representative." The Committee may agree to consider a communication submitted on behalf of an alleged "victim" when it appears that the "victim" is unable to personally submit the communication. The "representative" then has the burden of demonstrating the grounds and circumstances justifying the action on behalf of the victim. ${ }^{221}$ The extent to which this interpretation will increase individual access to the Committee depends upon the breadth of the Committee's interpretation of "representative," and of the grounds and circumstances which are deemed to justify "representatives" acting on behalf of an alleged "victim."

Associated with confining standing to "victims," is the requirement that they be subject to the jurisdiction of the State Party charged with violating the requirements of the Covenant. It appears that an individual has no remedy under the Optional Protocol if a State Party violates the individual's rights while the individual is outside the territorial jurisdiction of that State. ${ }^{222}$

Assuming that a "victim's" rights have been violated while subject to the jurisdiction of a State Party to the Optional Protocol, the individual or the individual's "representative" may submit a written communication to the Committee. Such communications are inadmissible if, among other reasons, they are "incompatible [e.g. 'outside'] with the provisions of the Covenant." 223 This provision assumes individual "victims" have a familiarity with the substantive provisions of the International Covenant on Civil and

221. Id.

222. "The conclusion seems inescapable that the scope of the procedural protection afforded by the Protocol cannot be wider than that of the Covenant." Schwelb, supra note 120, at 180-81. Under Article 2(1) of the Covenant a State Party shall respect and ensure the rights recognized in the Covenant to all individuals within its territory and subject to its jurisdiction. The words "within its territory" thus apply as a limitation in the Optional Protocol. It also should be noted that such a "territorial limitation" does not appear in any other major human rights instrument.

223. The Article 3 requirement of not allowing anonymous communications is defensible in that it prevents communications submitted in "bad faith." However, it also may subject complainants to reprisals. The inadmissibility of anonymous submissions, considered by "the Committee to be an abuse of the right of submission," would appear to permit exclusion of "trivial," "inflammatory" communications, and those submitted for the purpose of "harassing" State Parties. 
Political Rights. In addition, "incompatibility" is a question of legal interpretation, which the Human Rights Committee, a nonjudicial organ, is ill-equipped to undertake. Domestic courts have long struggled with the scope of rights contained in the Covenant, such as the "right of peaceful assembly," "freedom from torture or cruel, inhuman or degrading treatment or punishment," and "freedom of thought, conscience and religion." For instance, the Committee may have to determine whether "freedom of thought, conscience and religion" encompasses the "right to conscientious objection" to "war in any form" or to a "particular war." Even if it does, there is the further question of whether the right of "particular conscientious objection" would be qualified by Article 18(3), which subjects "the freedom of thought, conscience and religion" to limitations "prescribed by law" that are "necessary to protect public safety, order, health, or morals or the fundamental rights and freedoms of others."

The Committee also "shall not consider" any communication from an individual "unless it has ascertained that all domestic remedies have been exhausted," (unless such remedies are "unreasonably prolonged"), and unless the same matter is not being examined "under another procedure of internal investigation or settlement." The exhaustion requirement seems to be designed to clarify issues, economize resources, insure efficiency and respect state sovereignty. The application of the exhaustion requirement has been criticized in cases where individuals may be subjected to denials of life and liberty.

One assumes that the domestic remedies rule has been incorporated into the . . . procedure for a purpose, but the purpose remains unclear. . . . It was born in a commercial world for the protection of states confronted with suits by other states espousing claims of their nationals and is still applied in that context. . . . The relief sought in commercial claims is generally money; in human rights cases, it is generally life or liberty.

There are serious problems facing the individual who attempts domestic remedies for a violation of human rights by his government .... [If] governmental authority is being challenged, the pursuit . . . is likely to be futile; furthermore, the individual may be placing himself in great personal danger. . . . 224

224. Manke, The Exhaustion of Domestic Remedies in the United Nations Subcommission on Prevention of Discrimination and Protection of Minorities, 24 Buffalo L. ReV. 643, 644-45 (1975). 
The exhaustion requirement might be modified in cases where there is the possibility of "immediate and or irreparable harm" to the complainant.

The Committee also "shall not consider" a communication if "the same matter" is being "examined under another procedure of international investigation or settlement." The question arises whether the bar against considering "the same matter" might be interpreted as to impede the Committee's effectiveness under the Optional Protocol. For instance, it may preclude Committee consideration of an individual communication alleging inhumane conditions of incarceration in a State Party's prisons if the general conditions in the State Party's prisons are under investigation by the United Nations Human Rights Commission. The Covenant's provision for deference to other international bodies seems to be designed to economize the Committee's resources and to clarify the issues in dispute prior to the consideration by the Human Rights Committee. If the Committee chooses not to defer, but reviews and disagrees with the findings of another tribunal, or conducts its own de novo investigation, such action could waste the Committee's resources and damage its prestige. The solution to the problem of priority among competing international human rights procedures would seem to lie in standardization of international organizational practices. $^{225}$

Once a communication is brought to the attention of the State

225. Tardu, supra note 218 , at $784-85$ offers a comprehensive discussion of the problem of competing international procedures. The preparatory work in the Third Committee of the U.N. General Assembly in 1966 manifested a trend toward a stronger assertion of the powers of the Human Rights Committee vis- $d$-vis competing international procedures. The principle una via electa was gradually abandoned in favor of the present system of adjournment of proceedings pendente lite. An initial draft of the article would have precluded action by the Human Rights Committee in all cases where any implementation procedures set forth in other instruments would have been invoked. Id. at 784, citing U.N. Doc. A/C.3/L.1399. The proposal was withdrawn after many delegates had expressed the view that the proposal would unjustifiably place the Human Rights Committee in a subsidiary position vis- $d$-vis competing organs, and for all intents and purposes, "nullify" the Committee. Id., citing Records of the 1432nd and 1433rd Meetings of the Third Committee, U.N. Docs. A/C.3/ SR.1433, para. 12. Later on in the debates amendments were put forward providing that the Human Rights Committee would not consider complaints from individuals if the same matter had already been "submitted" to another procedure of international investigation or settlement. Id., citing U.N. Doc. A/C. 3/L. 1355, para. 2 and A/C.3/L. 1402/ Rev.2. This formula was revised to include the language "is being examined." U.N. Doc. A/C.3/L. 1411/Rev.2. The present formula finally was adopted with 54 votes in favor, none opposed and 29 abstentions. Id., citing Summary Record of the 1446th Meeting of the Third Committee, U.N. DoC. A/C.3/SR.1446. Tardu argues that the Committee would be authorized to consider a communication even if the matter is being examined under a competing international procedure if the Committee feels the competing procedure is "unreasonably pro- 
Party concerned, the "receiving state" has six months to submit to the Committee written explanations, or statements clarifying the matter and the remedy, if any, that may have been taken by that State. 226 Six months appears to be too extended a period within which to respond in situations involving emergencies or irreparable harm. Provision should be made in such situations for an expedited response and some form of injunctive relief.

The Committee is to consider communications and States Parties' responses in "closed meetings." 227 However, unlike the Article 41 interstate complaint procedures, no provision is made in the Optional Protocol for any representatives of the parties concerned to be present when the Committee is considering "the matter." This places the alleged "victim" at a disadvantage, since "victims" usually do not have the resources available to States Parties. Without some form of representation and procedural rights during committee deliberations, "victims" are unlikely to be able to successfully rebut the contentions of States Parties. ${ }^{228}$

The Human Rights Committee's ability to fulfill its responsibilities under the Optional Protocol is limited by the fact that its resources must be divided between performing its responsibilities under Articles 40, 41 and 42 and under the Optional Protocol. The Committee appears designed primarily to perform nonjudicial, fact-finding and conciliation roles under Articles 40, 41 and 42. Yet, under the Optional Protocol the Committee is also required to serve a quasi-judicial function and "forward its views" to the State Party and individual concerned. It is open to question whether committee members, in "formulating their views," can resist the influence of their own governments, or their own political views on the concept of individual petition. ${ }^{229}$ On the other hand, even if the Committee's "views" are adverse to a State Party, the Committee

longed." Id., citing Summary Records of the 1441st and 1446th Meetings of the Third Committee, U.N. Docs. A/C.3/SR. 1441, para. 20 and A/C.3/SR. 1446, para. 16.

226. It is not clear whether the Committee will examine the adequacy of the remedy provided. For instance, a state only may provide for a conciliation or an arbitration remedy and not provide compensation for parties whose rights have been violated. In such a case the question arises whether the Committee would analyze the adequacy of the remedy provided the complaining party.

227. Civil and Political Covenant, supra note 101, art. 5(3).

228. There is no provision in the Protocol for informing individual "victims" that their petition has been received; of the response by the State Party concerned; or when the matter will be heard. For a discussion of the problems faced by poorly educated defendants, see $P$. DRosT, supra note 5, at 112-13.

229. There is no provision for dissenting opinions. 
has no ability to enforce its judgment. ${ }^{230}$

\section{An Evaluation of the International Covenant on Civil and Political Rights}

Critics of the United Nations human rights instruments have suggested evaluation efforts may "preempt a disproportionate share of the limited time and energy for human rights work." They contend that the instruments may "foster a harmful illusion of accomplishment" and "serve as an excuse for failure to pursue more practical courses of action." 231

In contrast, Schwelb views the United Nations' human rights instruments as an important first step towards protection of universal human rights.

[W]ith all its deficiencies and its lack of system and symmetry, the work of the United Nations in the human rights field has, from its beginnings, been a dynamic and by no means insignifcant operation. . . .

[W]hile the conclusion of international treaties does not in itself guarantee that they will in practice be respected, they certainly are a step towards this goal. As to 'declarations,' . . . [they] may by custom, become recognized as laying down rules binding

230. Capotorti, supra note 116, at 144, observes that the shortcomings of the Protocol must be appreciated in the context of the Protocol's bold provision for individual petition:

If we think of the deep reluctance on the part of governments to be placed on the same level as the individuals, before an international body, we shall fully realize the importance of the petition procedure, and at the same time the difficulty to make [sic] it more efficient. This difficulty is even greater because the said procedure could bring to a comparison between the point of view of a State Party and that of one of its nationals, both of which must be equally and carefully considered by the competent international body, when all the State's domestic remedies have been exhausted without giving satisfaction to the individual. If we bear this in mind, it will be easy to understand the optional character of the petition machinery.

Capotorti, goes on to argue that the non-judicial character of the Protocol dictates that the Committee be confined to exercising "modest powers."

[W]ere individual petitions to be followed by more adequate international acts, including the condemnation of the State which has failed to observe its obligations, it would be absolutely necessary to ascertain the facts and to implement the relevant clauses of the agreement through a judiciary proceeding. In fact, as long as the examination of the petitions is entrusted to a non-judiciary organ and is carried out on the basis of a restricted investigation, without the guarantees connected with judicial proceedings, it will logically be concluded only with suggestions and recommendations, or with the expression of "views" from the competent organ, which have a political more than a legal value.

Id. Bilder, supra note 219, at 211 suggests that the Optional Protocol should not be viewed as a mechanism to be used in all cases of violation of human rights, but that it should be used ". . . where the exercise of the right of petition is likely to prove in effect a class action, revealing and potentially remedying pervasive human rights denials, it would seem capable of promoting human rights in a significant way."

231. Id. at 205. 
upon States. ... [S]urveys, studies and reports . . . are 'not only a source of information, but also a valuable incentive to Governments' efforts to protect human rights and fundamental freedoms. ${ }^{232}$

Bilder points out that instruments, such as the International Covenant on Civil and Political Rights, might raise general standards of international conduct and place pressure on governments to implement internal reforms.

Arguments favouring reliance on declarations and conventions emphasize that they define the content of human rights concepts and establish clearer standards of governmental conduct. They educate both officials and the general public in these norms, place governments failing to respect human rights on the defensive, and help create and legitimate internal and external pressure for human rights improvement. Conventions lift general standards to the level of concrete binding rules.

Perhaps most important, declarations may stimulate and conventions require, enactment of internal legislation to implement applicable human rights standards. . . . In some cases they may help a government to legitimate reforms it itself wishes to undertake. Even where such legislation is initially pro forma, it tends over time to have a growing normative impact. ${ }^{233}$

Other scholars, while appreciating the importance of the International Covenant on Civil and Political Rights, feel that its effectiveness is limited by the Covenant's obvious shortcomings. Clark finds a number of areas "in which the present situation is unsatisfactory."234

1. Principles are formulated in treaty form but this is not followed by ratification by all, or even by a majority of states.

2. Ratified Treaties are not given practical application.

3. Enforcement procedures contained in the treaties are limited.

4. 'Communications' receive cavalier treatment.

5. Limited sources of information are available to United $\mathrm{Na}$ tions human rights bodies.

6. Only limited use is made of NGO assistance and representation [this overlaps with 4 and 5].

7. There is a meagre response to requests for periodic reports

232. Schwelb, Remarks at International Conference About the European Convention on Human Rights, Vienna, Australia October 18-20, 1965, in A.H. RoBerTson, supra note 5, at 307-17.

233. Bilder, supra note 219 , at 205.

234. R. Clark, supra note 57. See also Bilder, The International Promotion of Human Rights : A Current Assessment, 58 AM. J. INT'L L. 728 (1964). 
and ineffective techniques for dealing with those received. ${ }^{235}$

Unlike Clark, Capotorti focuses on the Covenant's inadequate implementation procedures.

(a) The periodic reports by the States are the subject of a superficial consideration which shall lead only to recommendations of a general nature.

(b) The procedure for settlement of disputes is essentially based on goodwill of the states can be interrupted by either State Party to the dispute before the Conciliation Commission has been appointed, and does not include any possibility of unilateral application to a judiciary organ [sic].

(c) Individual petitions can easily be considered as unadmissible [sic], by the receiving organ, and even if they are admitted, they are not followed up by an investigation of the facts or by ascertainment of the alleged violation: the Human Rights Committee shall confine itself to express its views. ${ }^{236}$

\section{Capotorti concludes}

that the reports . . . rather than control measures, are a means of information . . . . As to the procedure for the settlement of disputes provided for in the Covenant on Civil and Political Rights, it is nothing but a prolonged attempt of conciliation, while the examination of petitions provided for in the Optional Protocol represents only a means for political pressure, which is far from being too strong. ${ }^{237}$

These shortcomings in the International Convenant on Civil and Political Rights are, in part, a reflection of the fact that the "United Nations is neither an objective Tribunal nor a world government, but a political organization ... . The result is a politicalization of human rights." 238

[S]tates still guard their national sovereignty dogmatically and they have yet to perceive a common interest in internationalizing and institutionalizing implementation measures; and . . . the position of the individual in international law is still anamalous, for while he is considered the object of international law, many states still refuse to consider him an appropriate subject of international law so as to entitle him to invoke the international machinery on his own behalf. ${ }^{239}$

235. R. Clark, supra note 57, at 39.

236. Capotorti, supra note 116 , at 146.

237. Id.

238. Saario and Cass, The United Nations and the International Protection of Human Rights : A Legal Analysis and Interpretation, 7 CALIF. W. INT'L L.J. 591,606 (1977).

239. Nanda, Implementation of Human Rights by the United Nations and Regional Organizations, 21 DE PAUL L. Rev. 307, 321 (1971). 
The Civil and Political Covenant may then be viewed as a political document rather than as a legal declaration. The Covenant should be seen as a symbolic commitment by states to human rights. Perhaps, for that reason the implementation procedures may be deliberately full of "vague standards, crippling exceptions and numerous escape hatches." 240

The politicalization of human rights in the United Nations is reflected in the fact that serious discussions of both civil and political rights have tended to concentrate on those "politically safe" areas where there is international consensus-opposition to apartheid and anticolonialism.

[W] hile [smaller nations] frequently demonstrate great concern over apartheid and colonialism and vote for stern measures against the violation of human rights in South Africa and Rhodesia, they do not show a similar concern over violations of human rights in other settings. In the latter situations their approach is invariably cautious, and their recommendations are for considerably weaker measures of implementation. ${ }^{241}$

Many flagrant examples of human rights violations are passed over in silence while the transgressions of one nation are singled out for overwhelming opprobrium. . . [G]overnments tend to express such concern only if a showing of official outrage over the violations would be likely to serve some political interest. ${ }^{242}$

The Civil and Political Covenant also suffers because the substantive human rights provisions of the Covenant contain a liberal democratic ideological bias. This bias results from the fact that the Covenant was drafted prior to the entry of over fifty new, largely third-world states into the United Nations. As a result, the values of Western industrialized countries are dominant. In addition, the Covenant was drafted in part as an ex post facto statement of allied war aims during World War II. Professor Inis L. Claude Jr. views the Covenant's provisions as "hastily generalized from immediately preceeding experience ... . [and as] an attempt to equip the world

240. Bilder, supra note 219, at 206. MacChesney, Should the United States Ratify the Covenants? A Question of Merits: Not of Constitutional Law, 62 AM. J. INT'L L. 912, 914 (1968). MacChesney notes,

[I]t is somewhat ironic to note that the voting majorities that extended the scope of the substantive provisions at the same time weakened considerably the provisions for enforcement, particularly with respect to the final implementation provisions in the Civil and Political Covenant.

MacChesney's comment suggests States saw the Covenant primarily as a political rather than as a legal document.

241. Nanda, supra note 239, at 322.

242. Saario and Cass, supra note 238, at 606-07. 
for dealing with Hitler-after Hitler was already dead."243

Thus, the Covenant has catalogued activities, and labeled them as "rights," with little clarification as to the rationale, scope and nature of such categorization. ${ }^{244}$ The confusion surrounding the concept of human rights is reflected in the statement that: "[M]uch has been said about them [human rights], and yet one may still be left wondering what they are."245 Bilder observes that this definitional problem is "not trivial ... [ [and that] what we think human rights really are will inevitably influence not only our judgment as to which types of claims to recognize as human rights, but also our expectations and programs for implementation and compliance with these standards." 246 A hierarchy must also be structured for ranking conflicting rights, and for determining which new "claims" qualify as "human rights." The arbitrary categorization of a variety of spheres of activity as rights can only lead to frustration and disillusionment with United Nations human rights activities. $^{247}$

In short, the human rights vocabulary is marked by ambiguity and imprecision. It invites political, not legal, discourse and sanctions capricious conduct on the part of local and international authorities because it does not provide juridical standards for the definition of rights and their violations. . . .

The phrase 'human rights' does not refer to legal propositions or to rcalities as these are perceived today. In its most positive meaning it institutes a list of desires, political goals, or ideological commitments. Read negatively, but equally justifiably it may be likened to a paper blanket covering up the absence of real and enforceable rights of the kind customary under Western constitutionalism. $^{248}$

United Nations activities have emphasized the drafting and

243. I.L. Claude Jr., Swords Into Plow Shares : The Problems and Progress of INTERNATIONAL Organization 70-71 (3rd ed. 1964).

244. See McDougal, Lasswell and Chen, Human Rights and World Public Order : Human Rights in Comprehensive Context, 72 Nw.U.L. REv. 227, 281 (1977); Nanda, supra note 239, at 308; Bilder, supra note 219 , at 173-74.

245. M. Cranston, supra note 5, at 1 .

246. Bilder, supra note 219 , at 174.

247. For discussion of the definition of a human right see Benn, Rights, 7 ENCYCLOPAEDIA OF PHILosophy $195-99$ (D. Edwards ed. 1967); Berlin, Two Concepts of Liberty, in Four Essays on Liberty 118 (1969); D. Braybrooke, Three Tests for Democracy (1968); M. Cranston, supra note 5; Feinberg, Duties, Rights and Claims, 3 AM. Philosophical QUARTERLY 137-44 (1966).

248. Bozeman, Understanding the Communist Threat, in A. Said ed., supra note 15, at $144-49$. 
ratification of human rights resolutions and covenants. ${ }^{249}$ The protection of civil and political rights must involve increased international efforts to create a socio-economic environment within each nation-state which is compatible with the dignity of the individual. ${ }^{250}$ The protection of human rights is fundamentally a problem of domestic implementation and politics. A greater effort must be made towards linking international and domestic protections.

[M]ore emphasis should be given to advisory services types of programs such as technical advice, education and seminars; to meaningful reporting by countries; and to first-rate and realistic studies of a particular countrys' problems. More work might be done at such elementary levels as encouraging the formation of national groups interested in human rights: promoting legal-aid programs; and helping such primary level official agencies as local police, school teachers, village magistrates, and tribal chieftains to better understand what in practice human rights on the local level mean.

. . . Countries should be encouraged to assign competent and well informed people to international human rights work. ${ }^{251}$

Protection of civil and political rights requires the development of techniques for international fact-finding, and for effective use of publicity and world public opinion. "Experience shows that governments are in fact sensitive to world opinion, and it is often the only weapon at our disposal."252 In short, the Human Rights Committee must become an "active" rather than a "passive" organ. It must also initiate studies and publicize its findings. A more aggressive role for the Human Rights Committee might entail greater support for nongovernmental organizations, which are, in many cases, a politically neutral force capable of bringing public opinion to bear on governments. ${ }^{253}$

249. See generally Fisher, Bringing Law to Bear on Governments, 74 HARV. L. REV. 1130 (1961).

250. The influence of such factors is recognized in the proclamation of Teheran, Final Act of the International Conference on Human Rights, U.N. Doc. A/Conf. 32/41 (1968). See Trubek, When is An OmJet? What is An Egg? Some Thoughts on Economic Development and Human Rights in Latin America, in Sixty-Seventh ANNual Proceedings of AMeruCAN SOCIETY OF INTERNATIONAL LAW No. 598 (1973); and Wachtel, The Epoch of Socialism and the Integration of World Capitalism, id. at 221.

251. Bilder, supra note 234, at 732-33.

252. Id. at 733 .

253. See Weissbrot, The Role of International Non-Governmental Organizations in the $1 \mathrm{~m}$ plementation of Human Rights, 12 TEX. INT'L. L.J. 293 (1977); Green, NGO's, in A. Said ed., supra note 15, at 304-17; Luard, Conclusion, in E. Luard ed., supro note 5, at 304-17; Prasad, The Role of Non-Governmental Organizations in the New United Nations Procedures for Human Rights Complaints, 5 DENVER J. INT'L L. \& P. 441 (1975). 
1. Possible Reforms. Most importantly, the substantive provisions and implementation procedures in the International Convenant on Civil and Political Rights must be reexamined. A number of reforms have been suggested, some of which deserve serious study and analysis by human rights activists and scholars.

1. The establishment of a United Nations High Commissioner for Human Rights has been proposed. Generally, the various proposals view the High Commissioner as an ombudsman who collects and examines information on human rights in various states and who serves as an advocate for human rights throughout the world. ${ }^{254}$

2. A related proposal calls for the creation of a United Nations Organization for the Promotion of Human Rights (UNOPHR) whose main organ would be a Human Rights Council. The creation of this organization is designed to emphasize the importance of human rights and provide for their efficient protection. ${ }^{255}$

3. Another structural reform calls for the creation of a Human Rights Assembly in which the peoples of the United Nations would be directly represented in a permanent world forum. The assembly would discuss human rights problems, advise the General Assembly, and serve as a liaison with national parliaments. ${ }^{256}$

4. A proposal requiring extensive study is the creation of a World Court of Human Rights empowered to issue binding decrees in disputes concerning human rights. This proposal entails consideration of the efficacy and role of law in protecting human rights. ${ }^{257}$

5. A variant of the World Court of Human Rights is the proposed concept of a "World Habeas Corpus" for any imprisoned individual. $^{258}$

254. See R. ClaRK supra note 57; Etra, International Protection of Human Rights: The Proposal for a United Nations High Commissioner, 5 Colum. J. Transnat'L L. 150 (1966); Fawcett, Remarks at International Conference about the European Convention on Human Rights, Vienna, Austria October 18-20, 1965, in A. Robertson, ed., supra note 5, at 289-99. M. Moskowitz, Human Rights ANd World ORder 137-52 (1959); Newman, Ombudsmen and Human Rights: the New U.N. Treaty Proposals, 34 U. CHI. L. Rev. 951 (1967).

255. Sohn, United Nations Machinery for Implementing Human Rights, 62 AM. J. INT'L L. 909, 909-10 (1968).

256. Id. at $910-11$.

257. A. Goldberg, The Need for a World Court of Human Rights, 11 How. L.J. 621 (1965); Luard, Conclusion, in E. Luard ed., supra note 5, at 304-10; MacBride, The Strengthening of International Machinery for the Protection of Human Rights, in E. Luard ed., supra note 5, at 149-62.

258. Kutner, The Legal Ultimate for the Unity of Mankind, in L. Kutner ed.,supra note 5. See also Kutner, World Habeas Corpus and International Extradition, 41 U. DET. L.J. 525 (1963), Kutner, World Habeas Corpus: A Legal Absolute for Survival, 39 U. DET. L.J. 279 (1962). 
6. It has also been suggested that the approach of protecting human rights through comprehensive declarations and covenants be replaced by an incremental strategy entailing the drafting of instruments protecting particular rights which have wide-spread international support and which can be enforced effectively. ${ }^{259}$

7. A further suggestion is that human rights could be more effectively enforced through application of criminal sanctions on government officials responsible for human rights violations. ${ }^{260}$

8. Strong arguments have been made that human rights can only be effectively protected in a regional context where countries share common values and traditions, and appreciate one another's problems. The regionalization of human rights raises the question whether such "fragmentation" of international human rights activities is advisable. ${ }^{261}$

9. Discussion must take place concerning human rights in bilateral foreign policy, and consideration must be given to whether multilateral lending institutions should consider human rights criteria in their decisionmaking. ${ }^{262}$

10. The same approach cannot be used to effectively protect all human rights, and innovative techniques must be considered. These techniques might include the use of economic incentives to encourage human rights protection, the designation of artists and writers as "world resources" or the ransoming of "political prisoners."263

\section{CONCLUSION}

The problems encountered in drafting and implementing the International Covenant on Civil and Political Rights suggests that the document is largely a symbolic attempt at an international com-

259. E.B. HaAs, Human Rights and International Action (1970).

260. See J. CAREY, supro note 5, at 61-69.

261. Bilder, supra note 219, at 215-16. Buergenthal, International and Regional Human Rights Law and Institutions: Some Examples of Their Interaction, 12 TeX. INT'L L.J. 321 (1977).

262. See Kissinger, Continuity and Change in American Foreign Policy, The Arthur K. Salomon Lecture, New York University, in A. Said ed., supra note 15, at 154. For United States statutory provisions incorporating Human Rights see Salzberg and Young, The Parliamentary Role in Implementing International Human Rights: A U.S. Example, 12 TEX. INT'L. L.J. 251, 265-74 (1977).

263. Bilder, supra note 219 , at 216-17, writes that

The diversity of problems and goals, embracing much of human social experience, suggests the need for a similar diversity of approaches, tailored to particular needs, conditions, resources and possibilities.

See also Bilder, supra note 234, at 733. 
mitment to the well-being of individuals. The Covenant lacks procedures for effective fact-finding, for decisions on the merits of a complaint, and fails to provide for the authoritative sanctioning and public exposure of human rights violations. ${ }^{264}$ In addition, the Covenant's substantive provisions are imprecise and reflect a liberal-democratic bias.

A legal approach to human rights protection is limited by the fact that human rights violations are intertwined with problems of economic and political development. No agreement has been reached as to what other techniques might be effectively applied at the international level to protect human rights. Economic sanctions may hurt populations indiscriminately, damage the world economy, and create dangerous precedents. The use of force violates basic international norms and may lead to global destruction. The propagation of adverse publicity may make a Nation more intransigent, while expulsion from an international organization may interfere with attempts at establishing a dialogue and exerting subtle persuasion. Diplomatic pressure may lead to a politicalization of human rights and denigrate the concept of human rights. In addition, states probably could not agree on when or if nations would be justified in derogating from human rights principles in certain situations. ${ }^{265}$

The human rights movement has now officially marked its thirtieth anniversary. Thus far, the aspirations for the achievement of human rights have not been matched by authoritative provisions for expression of such ideals. The world may thus look forward to the popular movements for freedom continuing to be met by governmental repression and international apathy.

264. Bilder, supra note 219, at 206.

265. The most sophisticated research agenda is contained in McDougal, Human Rights and World Public Order: Human Rights in Comprehensive Context, 72 Nw.U.L. Rev. 227, at 280-307. But see Wood, Public Order and Political Integration in Contemporary International Theory, 14 VA. J. INT'L L. 423 (1974); Little, Toward Clarifying the Grounds of Value Clarification: A Reaction to the Policy-Oriented Jurisprudence of Lasswell and McDougal, 14 VA. J. INT'L L. 451 (1974). The most comprehensive discussion of techniques for safeguarding Human Rights is contained in J. CAREY, supra note 5. 